\section{Pacific Northwest}

National Laboratory

Operated by Battelle for the

U.S. Department of Energy

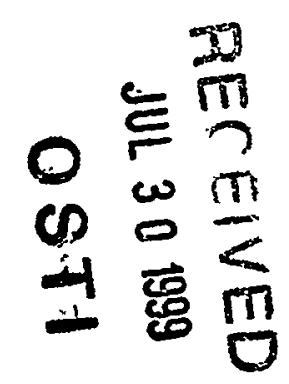

\title{
Drying Results of K-Basin Fuel Element 2660M (Run 7)
}

\author{
B. M. Oliver \\ S. C. Marschman \\ G. S. Klinger \\ P. J. MacFarlan \\ J. Abrefah \\ G. A. Ritter
}

July 1999

Prepared for the U.S. Department of Energy under Contract DE-AC06-76RLO 1830 


\section{DISCLAIMER}

This report was prepared as an account of work sponsored by an agency of the United States Government. Neither the United States Government nor any agency thereof, nor Battelle Memorial Institute, nor any of their employees, makes any warranty, express or implied, or assumes any legal liability or responsibility for the accuracy, completeness, or usefulness of any information, apparatus, product, or process disclosed, or represents that its use would not infringe privately owned rights. Reference herein to any specific commercial product, process, or service by trade name, trademark, manufacturer, or otherwise does not necessarily constitute or imply its endorsement, recommendation, or favoring by the United States. Government or any agency thereof, or Battelle Memorial. Institute. The views and opinions of authors expressed herein do not necessarily state or reflect those of the United States Government or any agency thereof.

\section{PACIFIC NORTHWEST NATIONAL LABORATORY operated by BATTELLE for the UNITED STATES DEPARTMENT OF ENERGY under Contract DE-AC06-76RLO 1830}

Printed in the United States of America

Available to DOE and DOE contractors from the

- Office of Scientific and Technical Information, P.O. Box 62, Oak Ridge, TN 37831; prices available from (615) 576-8401.

Available to the public from the National Technical Information Service, US. Department of Commerce, 5285 Port Royal Rd., Springfield, VA 22161 


\section{Drying Results of K-Basin Fuel Element 2660M (Run 7)}
B. M. Oliver
S. C. Marschman
G. S. Klinger
P. J. MacFarlan
J. Abrefah
G. A. Ritter

July 1999

Prepared for

the U.S. Department of Energy

under Contract DE-AC06-76RLO 1830

Pacific Northwest National Laboratory

Richland, Washington 99352 



\section{DISCLAIMER}

Portions of this document may be illegible in electronic image products. Images are produced from the best available original document. 


\section{Summary}

An N-Reactor outer fuel element that had been stored underwater in the Hanford 100 Area K-West Basin has been subjected to a combination of low- and high-temperature vacuum drying treatments. These studies are part of a series of tests being conducted by Pacific Northwest National Laboratory on the drying behavior of spent nuclear fuel elements removed from both the $\mathrm{K}$-West and $\mathrm{K}$-East Basins.

The drying test series was designed to test fuel elements that ranged from intact to severely damaged. The fuel element discussed in this report was removed from K-West canister 2660M in 1996 and has remained in wet storage in the Postirradiation Testing Laboratory (PTL, 327 Building) since that time. This element was split along the length in several places. One end of the element was breached, and the fuel was corroded and partly missing. K-West canisters can hold up to seven complete fuel assemblies, but, for the purpose of this report, the element is referred to as Element 2660M. In comparison with previous fuel elements in this test series, this element showed the most extensive damage to the cladding.

The drying test was conducted in the Whole Element Furnace Testing System located in G-Cell within the PTL. This test system is composed of three basic systems: the in-cell furnace equipment, the system gas loop, and the analytical instrument package. Element $2660 \mathrm{M}$ was subjected to drying processes based on those proposed under the Integrated Process Strategy, which included a hot drying step. The test cycles are listed below:

- Cold Vacuum Drying (CVD) at $\sim 50^{\circ} \mathrm{C}$ under vacuum $(\sim 18 \mathrm{hr})$

- Pressure Rise Test at $\sim 50^{\circ} \mathrm{C}(\sim 1 \mathrm{hr})$

- Hot Vacuum Drying (HVD) for a total of $\sim 67 \mathrm{hr}\left(\sim 25 \mathrm{hr}\right.$ at $\sim 80^{\circ} \mathrm{C}, \sim 35 \mathrm{hr}$ at $\sim 80^{\circ} \mathrm{C}$ to $\sim 400^{\circ} \mathrm{C}$, and $\sim 8 \mathrm{hr}$ at $\sim 400^{\circ} \mathrm{C}$ )

- System Cooldown to $\sim 50^{\circ} \mathrm{C}(\sim 53 \mathrm{hr})$

- Post-Test Pressure Rise Test at $\sim 50^{\circ} \mathrm{C}(\sim 1 \mathrm{hr})$.

Prior to CVD, $\sim 10 \mathrm{ml}$ of water were added to the system in addition to the water already on the surface of the fuel element to ensure the element was damp at the start of the test. Approximately $15 \mathrm{ml}$ of water were observed in the condenser during the condenser pumpdown phase of CVD, in reasonable agreement with a value of $13 \mathrm{~g}$ calculated over the same time period from the argon flow and moisture data. The observed water in the condenser, together with an equal amount observed in Run 4 (Element 5744), were the largest observed in the series of test runs. Observed pressure rise during the post-CVD Pressure Rise Test was $\sim 0.17 \mathrm{Torr} / \mathrm{hr}$, well below the acceptance criterion of $0.5 \mathrm{Torr} / \mathrm{hr}$. Similar to earlier tests, the total pressure rise observed in the post-CVD test was only partially caused by residual moisture, suggesting that other sources of gas are responsible for some of the total pressure rise 
observed in that test. Approximately $0.7 \mathrm{mg}$ of water was calculated to have been removed during the Pressure Rise Test. This water can likely be interpreted as coming from free water that was trapped and not completely removed during CVD.

Water removal during the three phases of HVD was $\sim 2.4 \mathrm{~g}, \sim 0.9 \mathrm{~g}$, and $\sim 0.017 \mathrm{~g}$, respectively. A main water release peak was observed during HVD-2 at $\sim 137^{\circ} \mathrm{C}$. Approximately $23 \mathrm{mg}$ of water was released during post-HVD cooldown, indicating small residual quantities of water remaining even after the drying test was completed. Water release during HVD-1 is attributed largely to the release of water from regions beneath the cladding and from under the corroded regions, with some release possibly from decomposition of metal oxy-hydrates. Water release during HVD-2 is probably from chemisorbed sites (i.e., hydrated species) at higher temperatures. As observed in previous drying tests, a temperature above $400^{\circ} \mathrm{C}$ may be required for complete drying of the fuel element within a reasonable period of time.

Hydrogen was observed during the test during a portion of the condenser pumpdown phase of CVD and during HVD. Hydrogen observed during CVD was $\sim 5 \mathrm{mg}$, and the data suggest that about $1 \%$ or less of the available water released during CVD is oxidizing the fuel. During HVD, hydrogen was first observed at the beginning of HVD-1, reaching a peak at $\sim 0.2$ Torr $1 / \mathrm{min}$ before slowly decreasing. Approximately $\sim 19 \mathrm{mg}$ of hydrogen were released during HVD-1, attributed largely to oxidation of the fuel by remaining free water. Hydrogen release increased again during HVD-2, with three noticeable peaks at $\sim 152^{\circ} \mathrm{C}(\sim 50 \mathrm{mg}), 194^{\circ} \mathrm{C}(\sim 39 \mathrm{mg})$, and $\sim 245^{\circ} \mathrm{C}(\sim 100 \mathrm{mg})$. The first two peaks roughly correlate with a similar water release and are likely due to oxidation of fuel by water released through oxy-hydrate decomposition. The third release peak is likely due to uranium hydride decomposition and represents about $8 \mathrm{~g}$ of $\mathrm{UH}_{3}$. Above $\sim 245^{\circ} \mathrm{C}$, the level of hydrogen decreased rapidly, with only $\sim 0.6 \mathrm{mg}$ of hydrogen being released during HVD-3. Total hydrogen release during HVD was $\sim 200 \mathrm{mg}$.

The water release characteristics for Element $2660 \mathrm{M}$ are very similar to those observed earlier for Element $5744 \mathrm{U}$ (Run 4). Element $5744 \mathrm{U}$ had shown similar levels of damage to the outer cladding and to one end. 


\section{Quality Assurance}

This work was conducted under the Quality Assurance Program, Pacific Northwest National Laboratory (PNNL) SNF-70-001, SNF Quality Assurance Program, as implemented by the PNNL SNF Characterization Project Operations Manual. This QA program has been evaluated and determined to effectively implement the requirements of DOE/RW-0333P, Office of Civilian Radioactive Waste Management Quality Assurance Requirements and Description (QARD). Compliance with the QARD is mandatory for projects that generate data used to support the development of a permanent High-Level Nuclear Waste repository. Further, the U.S. Department of Energy has determined that the testing activities which generated the results documented in this report shall comply with the QARD. Supporting records for the data in this report are located in the permanent PNNL SNF Characterization Project records, Furnace Testing of SNF Fuel Element 2660M. 


\section{Contents}

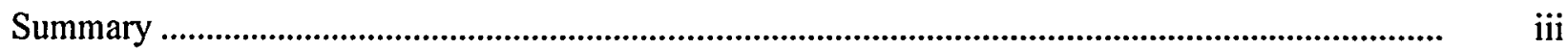

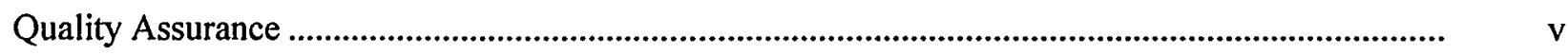

Acronyms ............................................................................................................................... x xii

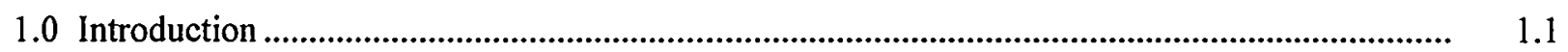

2.0 Whole Element Furnace Testing System ............................................................................. 2.1

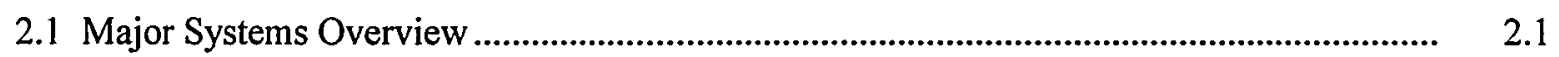

2.2 Vacuum Pumping System ............................................................................................ 2.4

2.2.1 Varian Scroll Pump .......................................................................................... 2.4

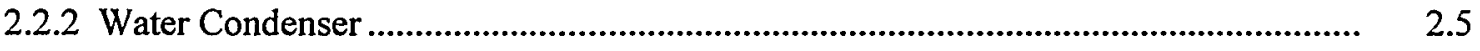

2.2.3 Piping, Valves, and Filters.................................................................................... 2.5

2.2.4 System Line Heaters....................................................................................... 2.5

2.3 Process Heating System ............................................................................................ 2.7

2.4 Gas Supply/Distribution System .............................................................................. 2.7

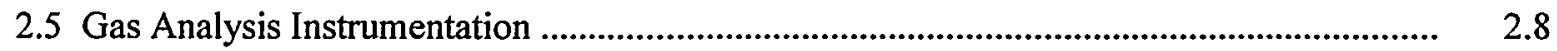

2.5.1 Balzers Omnistar Mass Spectrometer ................................................................... 2.8

2.5.2 MTI M200 Gas Chromatograph........................................................................... 2.8

2.6 Process Instrumentation ....................................................................................... 2.9

2.6.1 Panametrics Moisture Monitor .............................................................................. 2.9

2.6.2 MKS Baratron Pressure Transducers ................................................................... 2.10

2.6.3 Cole-Parmer Pressure Transducers....................................................................... 2.11

2.6.4 Thermocouples .................................................................................................... 2.11 
2.7 Data Acquisition and Control System

3.0 Vacuum Drying Testing of Element 2660M ....................................................................

3.1 Fuel Element Transfer and Loading .........................................................................

3.1.1 Pre-Test Visual Inspection ............................................................................. 3.1

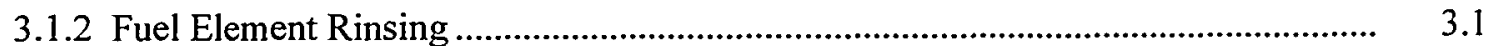

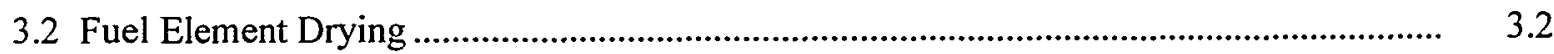

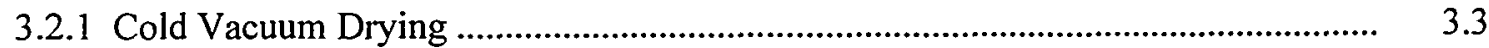

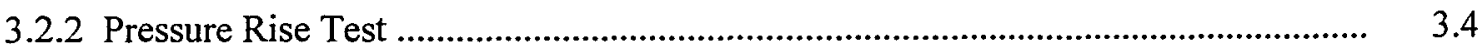

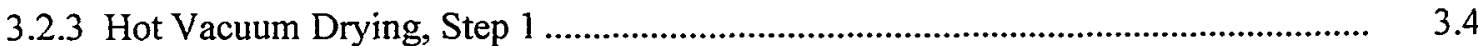

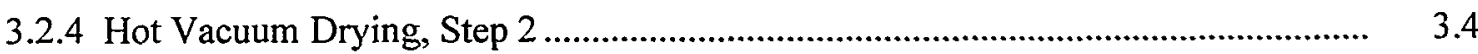

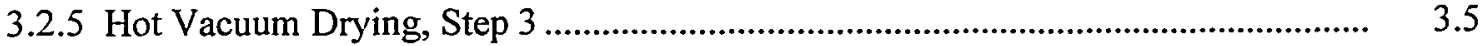

3.2.6 System Cooldown and Post-Test Pressure Rise Test .......................................... $\quad 3.5$

3.3 Calculation of Water and Hydrogen Inventories ................................................................. 3.5

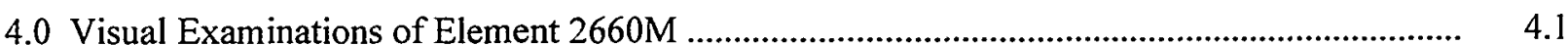

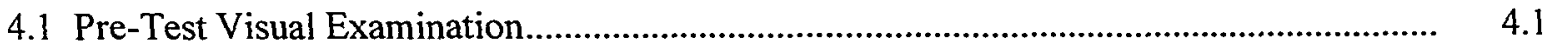

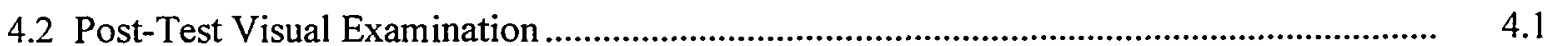

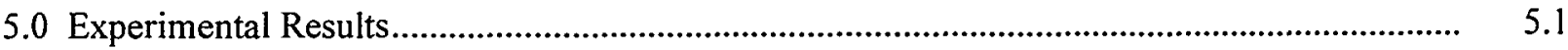

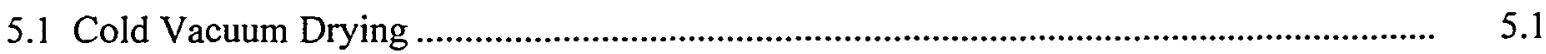

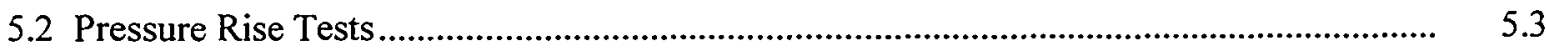

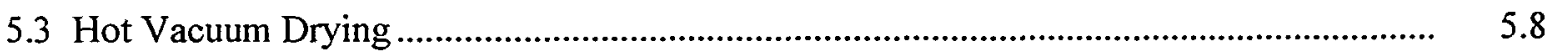

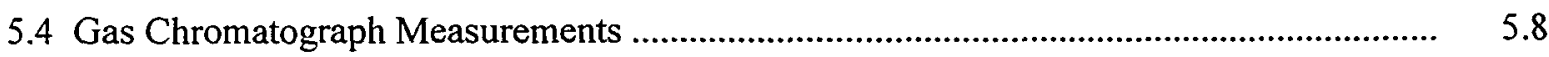

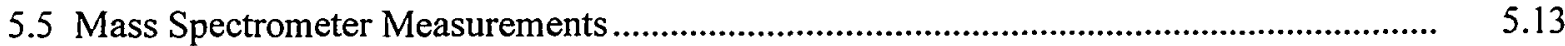

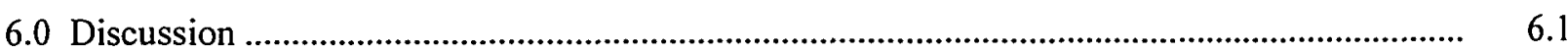




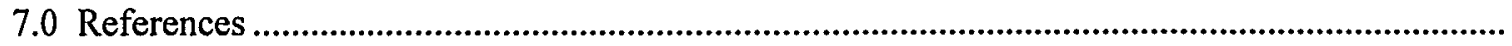

8.0 Supporting Documents and Related Reports........................................................................ 



\section{Figures}

2.1 Fuel Element Drying System Components (in-cell) ............................................................. 2.2

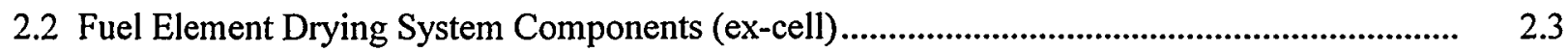

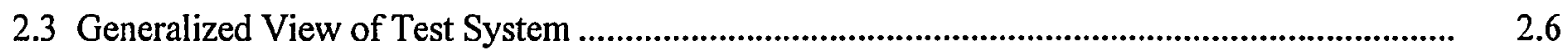

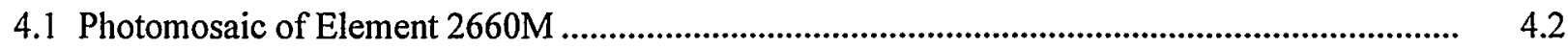

4.2 Photomosaic of a Large Longitudinal Crack on Element 2660M......................................

4.3 Post-Test View of a Crack in Element 2600M That Opened Significantly

During the Drying Test........................................................................................................

4.4 View of an Additional Crack That Opened During Drying. ...................................................

4.5 Powder-Like Particulates Recovered During the Post-Test Visual Examination of Fuel Element 2660M.

5.1 Drying of SNF Element 2660M, Summary Plot ...............................................................

5.2 Drying of SNF Element 2660M, Cold Vacuum Drying...................................................... 5.4

5.3 Drying of SNF Element 2660M, Post-CVD Pressure Rise Test ............................................ 5.5

5.4 Drying of SNF Element 2660M, Post-HVD Pressure Rise Test ...................................... 5.6

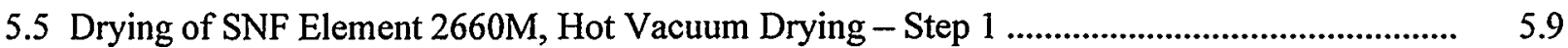

5.6 Drying of SNF Element 2660M, Hot Vacuum Drying - Step 2 ....................................... 5.10

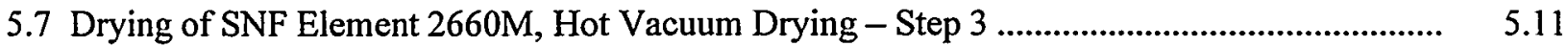

5.8 Drying of SNF Element 2660M, Hydrogen Release During CVD ..................................... 5.12

5.9 Drying of SNF Element 2660M, Hydrogen Release During HVD and Cooldown................... 


\section{Tables}

2.1 Water and Ice Vapor Pressure Data Versus Temperature

3.1 Summary of Nominal Test Design Conditions

5.1 Fuel Element 2660M Drying Run Time Line . 


\section{Acronyms}

$\begin{array}{ll}\text { ATS } & \text { Applied Test Systems } \\ \text { CVD } & \text { Cold Vacuum Drying } \\ \text { DACS } & \text { data acquisition and control system } \\ \text { DP } & \text { dew point } \\ \text { ET } & \text { elapsed time } \\ \text { GC } & \text { gas chromatograph } \\ \text { HP } & \text { Hewlett Packard } \\ \text { HVD } & \text { Hot Vacuum Drying } \\ \text { ID } & \text { inside diameter } \\ \text { IPS } & \text { Integrated Process Strategy } \\ \text { MS } & \text { mass spectrometer } \\ \text { NIST } & \text { National Institute of Standards and Technology } \\ \text { OD } & \text { outside diameter } \\ \text { PNNL } & \text { Pacific Northwest National Laboratory } \\ \text { PTL } & \text { Postirradiation Testing Laboratory } \\ \text { QA } & \text { Quality Assurance } \\ \text { QARD } & \text { Quality Assurance Requirements and Description } \\ \text { SFEC } & \text { single fuel element canister } \\ \text { VNF } & \text { spent nuclear fuel } \\ \text { ultra high purity } \\ \text { vapor pressure }\end{array}$




\subsection{Introduction}

The water-filled K-Basins in the Hanford 100 Area have been used to store N-Reactor spent nuclear fuel (SNF) since the 1970s. Because some leaks in the basin have been detected and some of the fuel is breached due to handling damage and corrosion, efforts are underway to remove the fuel elements from wet storage. An Integrated Process Strategy (IPS) has been developed to package, dry, transport, and store these metallic uranium fuel elements in an interim storage facility on the Hanford Site (WHC 1995). Information required to support the development of the drying processes, and the required safety analyses, is being obtained from characterization tests conducted on fuel elements removed from the K-Basins. A series of whole element drying tests (reported in separate documents, see Section 8.0 ) have been conducted by Pacific Northwest National Laboratory (PNNL) ${ }^{(a)}$ on several intact and damaged fuel elements recovered from both the K-East and K-West Basins.

This report documents the results of the seventh of those tests, which was conducted on an N-Reactor outer fuel element removed from K-West canister 2660M. This element (referred to as Element 2660M) was stored underwater in the K-West Basin from 1983 until 1996. Element 2660M was subjected to a combination of low- and high-temperature vacuum drying treatments that were intended to mimic, wherever possible, the fuel treatment strategies of the IPS. The system used for the drying test was the Whole Element Furnace Testing System, described in Section 2.0, located in the Postirradiation Testing Laboratory (PTL, 327 Building). The test conditions and methodologies are given in Section 3.0. Inspections of the fuel element before and after the test are provided in Section 4.0. The experimental results are provided in Section 5.0, and discussed in Section 6.0.

(a) Operated by Battelle for the U.S. Department of Energy under Contract DE-AC06-76RLO 1830. 


\subsection{Whole Element Furnace Testing System}

A complete description for the Whole Element Furnace Testing System, including detailed equipment specifications, is provided in Ritter et al. (1998).

\subsection{Major Systems Overview}

An overview of the furnace testing system is presented in this section. The subsystems pertinent to this test report are as follows:

- Vacuum Pumping System - This system consists of a scroll-type vacuum pump, a condenser with chiller, filters, valves, and piping, which provide the vacuum pressures and flows required for the proposed IPS vacuum processes.

- Process Heating System - This system consists of a resistively heated, clam-shell furnace and a sample chamber (retort) to provide heating to the fuel element and to control process temperatures.

- Gas Supply/Distribution System - This system consists of gas bottles; mass flow controllers; piping; and valves for metering argon, air, or oxygen through the system. A bubbler is also available for adding water vapor to the system if desired.

- Gas Analysis Instrumentation - The gas analysis instrumentation includes a 300-amu quadrupole mass spectrometer (MS) and a gas chromatograph (GC) for monitoring selected elements in the process gas stream.

- Process Instrumentation - The system is equipped with several instruments for measuring process temperatures, pressures, and moisture level. An auxiliary turbo vacuum pumping system provides low system pressures for zero adjustment of the high accuracy retort pressure sensor.

- Data Acquisition and Control System (DACS) - The DACS consists of an IBM-compatible computer and data acquisition/control unit to monitor/store key system parameters (temperatures, pressures, flows, moisture level), along with controlling the process heating system and a safety argon system.

Figures 2.1 and 2.2 are photographs of the equipment located inside and outside of G-Cell. The furnace (including retort) and some of the process piping, instrumentation, and valves are located inside the hot cell. The furnace sits on the cell floor, and the process piping is routed to a rack that hangs on the west cell wall. Process piping, electrical power, and instrumentation wires pass through several split plugs on the west side of the cell. The process piping on the outside of the cell is contained within a glove bag, which provides a secondary containment as a precaution in case the process piping lines 


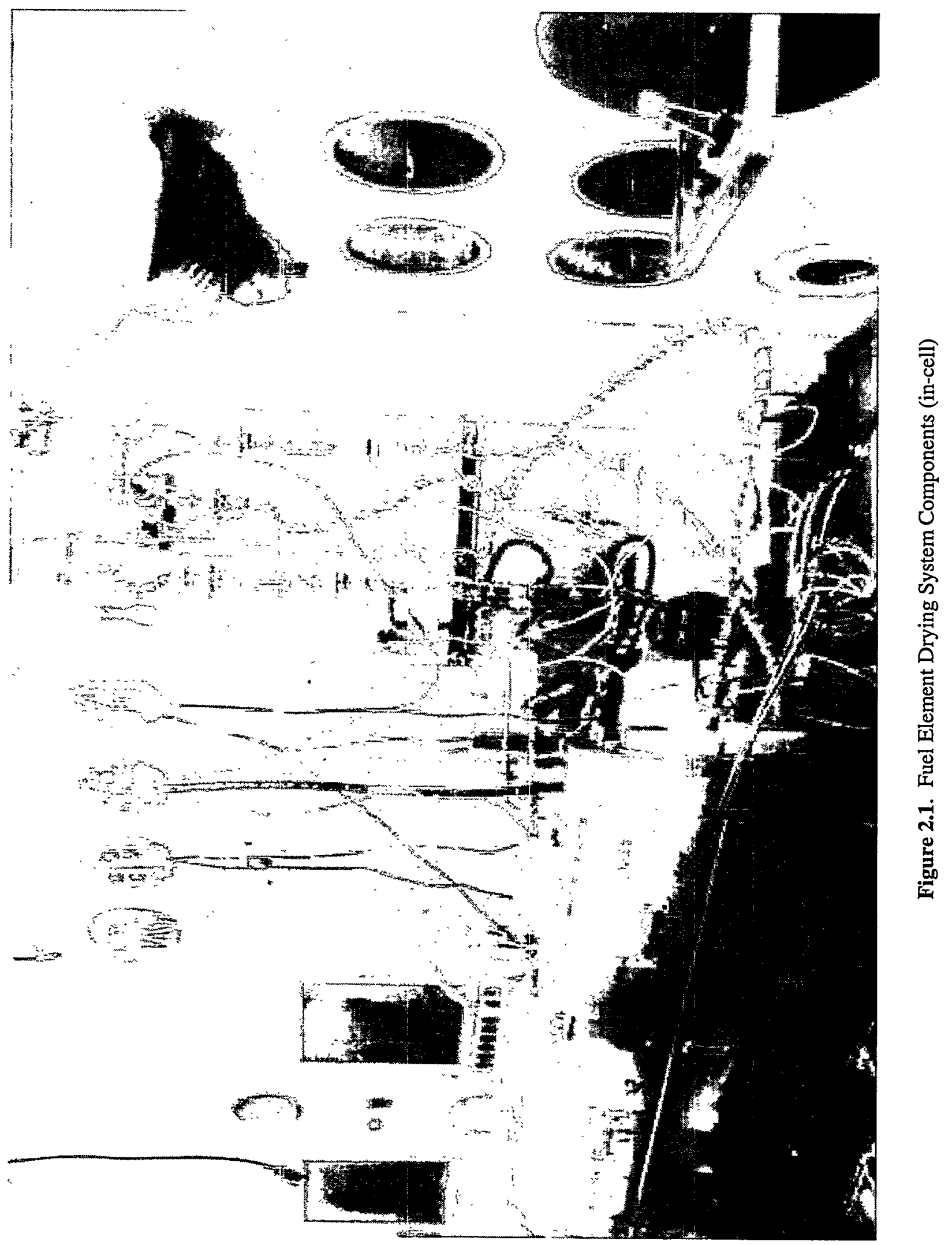




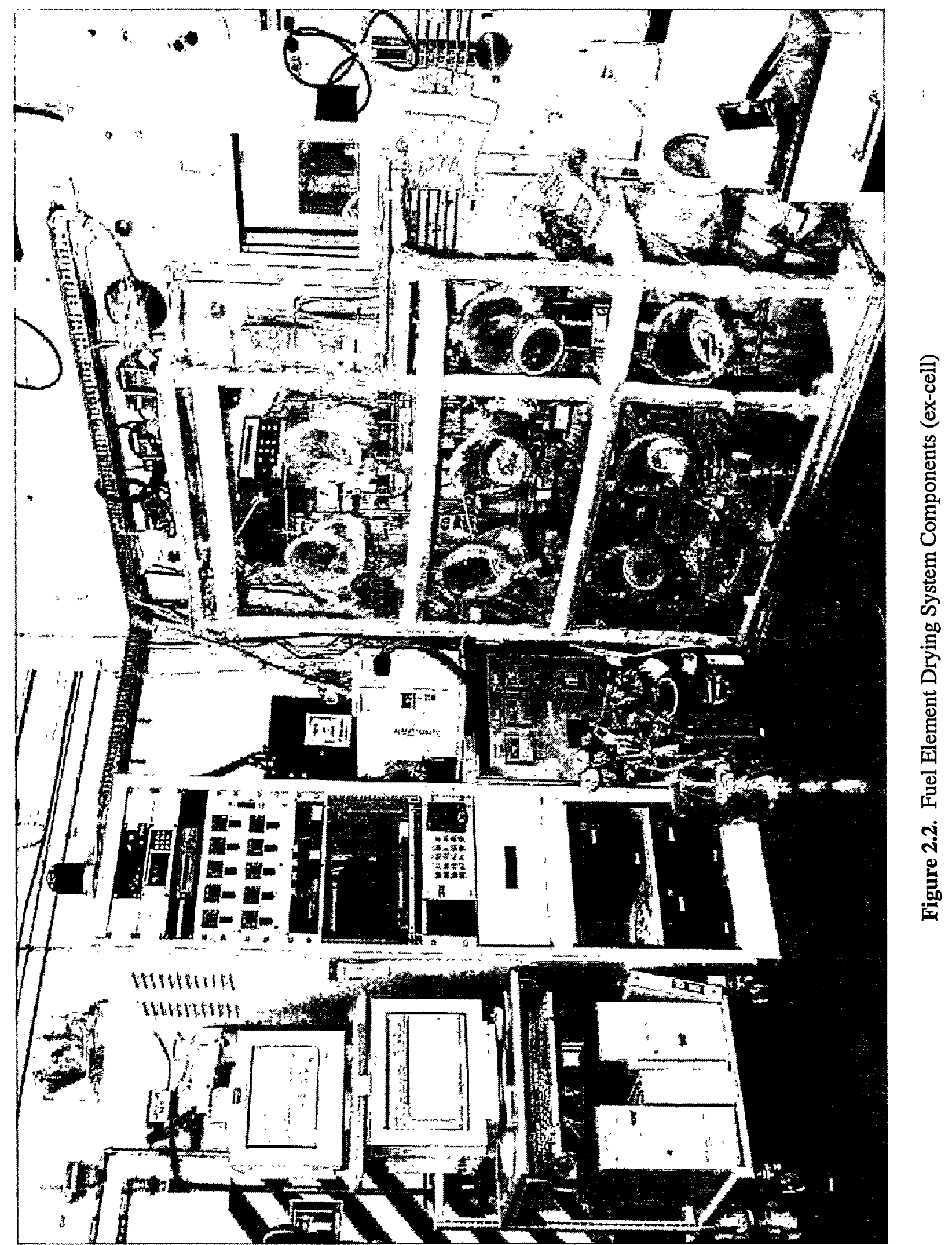


become contaminated. The vacuum pump, condenser, bubbler, GC, and the remainder of the instrumentation and valves are located inside this glove bag. Instrumentation and electrical power wires are routed through pass-through sleeves on the sides of the glove bag to the instrument rack and computer console.

The instrument rack contains the readout/control units for the pressure sensors, moisture sensor, and flow controllers, along with the heat trace temperature controllers, data acquisition/control unit, turbo pump controller, GC laptop computer, and uninterruptible power supplies. The computers for the DACS and MS are located next to the instrument rack. The following sections provide more detailed descriptions of the components for these subsystems.

\subsection{Vacuum Pumping System}

The vacuum pumping system provides the pressures and flows required for the proposed IPS processes. This system connects the furnace retort with all the other components of the test syste through various valves, fittings, and piping. The vacuum pumping system consists of the following components:

- scroll pump for evacuating the system to pressures below 1 Torr

- water condenser with refrigerated chiller for gross removal of water

- valves and piping for connecting the various components and controlling the flow direction

- particulate filters to prevent the spread of contamination

- heating cords with temperature controllers for preventing condensation in lines.

\subsubsection{Varian Scroll Pump}

The system vacuum pump is a Varian model 300DS scroll pump. This pump has an ultimate vacuu pressure less than $10^{-2}$ Torr and a peak pumping speed of $2501 / \mathrm{min}(8.8 \mathrm{cfm})$. These pressures and flows are more than adequate for simulating the conditions of the proposed IPS vacuum processes. For a single fuel element, this amount of flow may be more than desired. Therefore, a metering valve was installed on the pump inlet to throttle the flow to lower levels as required. The desired system pressure is achieved by either using the metering valve or flowing ultra high purity (UHP) argon into the system through the entire gas loop or via a direct injection of ballast gas at the pump inlet. The use of argon gas helps to prevent the in-leakage of moisture-containing air through small system leaks (which are difficult to eliminate) that would interfere with process monitoring equipment. 


\subsubsection{Water Condenser}

The scroll vacuum pump can be damaged by condensation of liquid water in the scroll mechanism, and, since each element was wet at the start of each test, the possibility of pump damage was considered. A water condenser with corresponding chiller was installed in the system to condense the bulk of the water before it reaches the pump. This condenser can be valved into the system in series with the scroll vacuum pump or can be bypassed if not needed. The condenser cannot trap all the liberated free water, but is efficient at removing the majority of free water in the system. The condenser is only used during the first phase of Cold Vacuum Drying (CVD). The condenser was custom fabricated specifically for this system. Detailed sketches and specifications for the condenser are given in Ritter et al. (1998).

\subsubsection{Piping, Valves, and Filters}

The vacuum pumping system connects the system components through various valves, fittings, and piping. A simplified piping schematic for the system is shown in Figure 2.3. This schematic shows the basic flow path of gases through the system that was used for this test, along with the relative locations of the major components, valves, and instruments. Detailed system piping diagrams are provided in Ritter et al. (1998), along with approximate lengths for the piping lines. As seen in Figure 2.3, there are numerous valves in the system that are used to direct the flow to and from the various components. Most of the valves in the system are ball valves and range from $1 / 4$ in. to $1 / 2$ in. nominal size. The system piping is constructed of thin wall tubing (1/4 in. to $1 / 2$ in. OD) and is typically connected using simple Swagelok fittings (tees, elbows, unions, etc.). Ports for gas sampling/analysis and monitoring of system pressure, temperature, and humidity are also provided at key locations in the system piping. Special fittings and pipe-threaded fittings are used in some locations for connecting piping to the process instruments.

Particulate filters are installed in the system on both the inlet and outlet to the retort to help prevent the spread of contamination to the system piping on the outside of the hot cell. These filters are constructed of a microporous fiberglass media in a stainless steel housing. They are $99.9 \%$ efficient for particulates that are 0.2 microns and larger in size. Two different size filters, manufactured by Matheson, are used in the system.

\subsubsection{System Line Heaters}

All of the stainless steel tubing that carries gases into the furnace retort and resultant gases from the retort is heated to about $75^{\circ} \mathrm{C}$ to ensure condensable water vapor remains in the gas phase. Simple heat "cords" capable of being wrapped upon each other (as required at tees, elbows, and other connections) were found to be a good heating method for this system. The heating cords are controlled by simple proportional controllers. Type-K thermocouples are installed on each heated line so the DACS can be used to monitor and record temperature. 


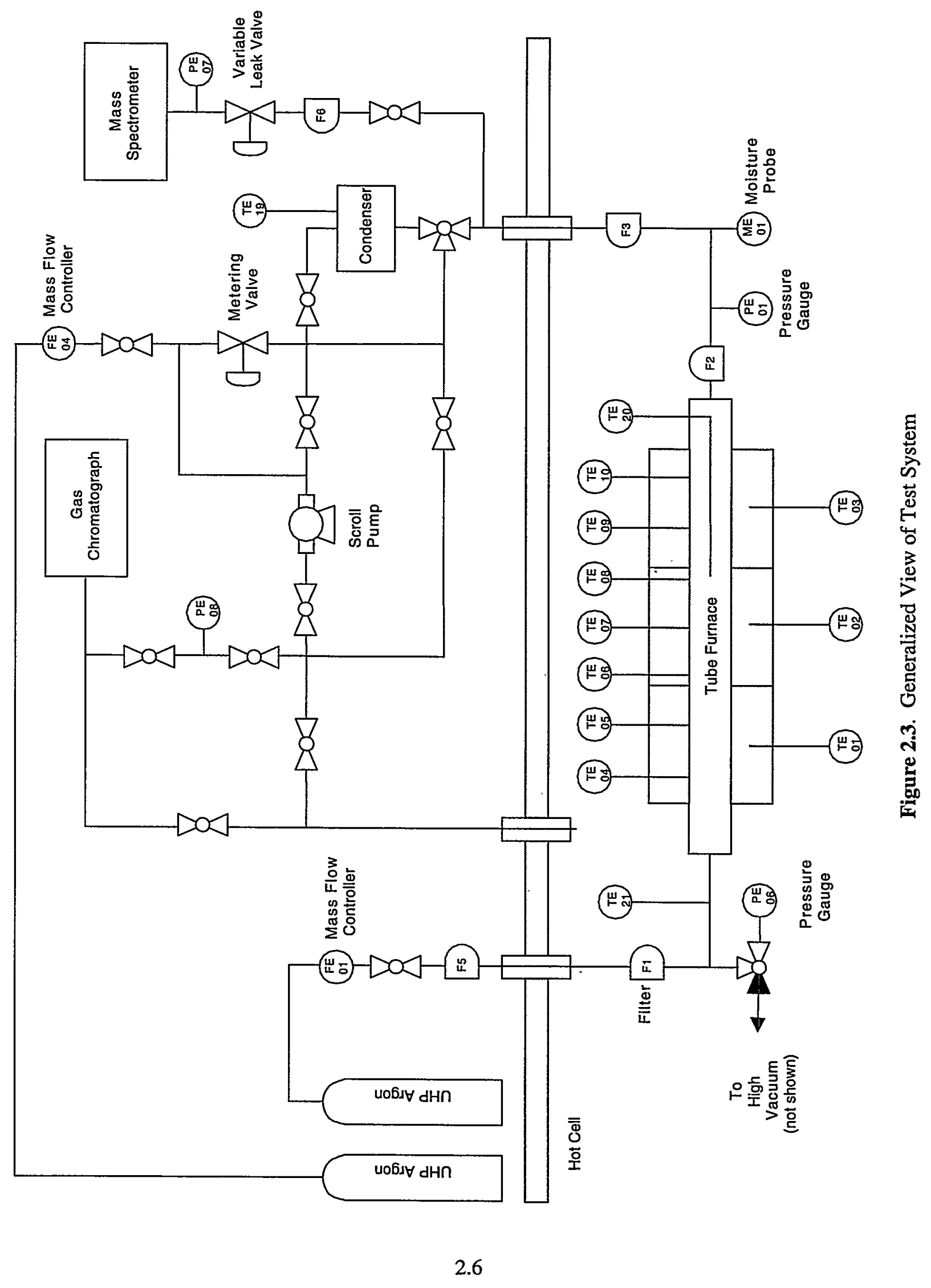




\subsection{Process Heating Syste}

The whole element furnace is a 4-ft long, resistively heated, clam-shell furnace. The furnace, a Series 3210 supplied by Applied Test Systems (ATS), has a temperature rating of $900^{\circ} \mathrm{C}$ and total heating capacity of $13,800 \mathrm{~W}$. The internal dimensions are $5 \mathrm{in}$. ID by $45 \mathrm{in}$. long. The furnace has three separate sets of heating elements that allow the heating to be controlled in zones; each zone is $15 \mathrm{in.} \mathrm{long} \mathrm{and}$ supplies up to $4600 \mathrm{~W}$ heating. The zones can be controlled separately to establish a flat temperature profile within the furnace, even though heat is lost preferentially out the end with the retort entry flange. A heat reflector consisting of several thin Inconel plates is used to reduce heat loss from the flange end of the retort. The furnace controller is an ATS Series 3000, which consists of three programmable, self tuning proportional with integral and derivative controllers. These controllers are also interfaced to the DACS, which is capable of providing limited input to the controllers as required.

The retort, an ATS Series 3910, is an Inconel tube fitted with a gas inlet tube at one end and a gasketed flange at the other. Of all high-temperature materials, Inconel series 600 was selected to reduce the amount of oxidation and water pickup by the retort and associated components. Experience has shown that stainless steel components were easily affected by corrosion, which could then affect test results. The body of the retort is fabricated from schedule 40 Inconel pipe ( $4.5 \mathrm{in.} O D, 4.026 \mathrm{in}$. ID), and the inside length is about 44.5 in. Seven type- $K$ thermocouples are installed equidistant along one side of the retort and extend into the retort interior approximately $1 / 8$ in. These thermocouples are used to monitor the retort temperature so that if a reaction with the fuel element occurs (which would locally raise the retort temperature), this event can be correlated with the approximate location on the fuel.

An Inconel sample/transfer boat is used to load the fuel element into the furnace. The boat is fabricated from an 11-gauge (0.120-in.-thick) Inconel 601 sheet, which is formed into a flattened u-shape. The boat has a weir and a swivel handle on each end. The weirs are used to keep free water or particulates contained in the boat as required.

\subsection{Gas Supply/Distribution Syste}

The gas supply system and vacuum pumping system together are capable of controlling the fuel element environment to vacuum or moderate pressure conditions, and/or exposing the fuel element to a variety of gases or gas mixtures. The gas loop is typically operated as a single-pass system with no capability for recirculation. The gas supply system consists of gas bottles; mass flow controllers; piping; and valves for metering argon, air, or oxygen through the system. A bubbler is also available for adding water vapor to the process gas stream as required, but it was not used in these tests.

The gas supply system contains three Matheson mass flow controllers calibrated for argon, air, and oxygen. All gases are typically specified "ultra high purity" and are additionally filtered for water using molecular sieve columns. Argon is the principal inert gas used, as it is more dense than air; provides reasonable thermal conductivity; and requires simpler handling procedures than lighter gases such as helium. The argon purge gas is introduced into the retort through FE-01, which is a Matheson model $8272-0422$ oxygen controller, recalibrated for argon gas at $25^{\circ} \mathrm{C}$ using a NIST-traceable bubble flow 
meter. Air and oxygen are not currently used because any oxidative steps have been deleted from the current IPS for the SNF. The manufacturer's specifications for the air and oxygen controllers' flow rate ranges are $0-280 \mathrm{sccm}$ argon, $0-1000 \mathrm{sccm}$ air, and $0-10 \mathrm{sccm}$ oxygen. If higher flow rates are desired, a new mass flow controller with a higher range could be procured and installed in the system.

\subsection{Gas Analysis Instrumentation}

\subsubsection{Balzers Omnistar Mass Spectrometer}

The Balzers Omnistar MS is a compact, computer-controlled, quadrupole MS capable of scanning to $300 \mathrm{amu}$. The unit is capable of monitoring up to 64 components within a gas stream with a nominal detection limit of less than $1 \mathrm{ppm}$ for most gases other than hydrogen. The MS was used to monitor hydrogen, nitrogen (for air in-leakage), krypton, xenon, and other elements during the test.

The MS was modified as a result of early system testing and calibration to improve the time response to small changes in hydrogen pressure. Before testing, the MS was calibrated for hydrogen using mixtures of hydrogen and helium, and hydrogen and argon gas. The residence time of each gas could be measured in the quadrupole chamber, and it was observed that the hydrogen decay time was approximately four times as long as helium. This was not unexpected as turbomolecular pumps have a lower pumping efficiency for very light gases. In standard practice this is acceptable, but for these tests, where determining hydrogen could be very important, steps were taken to improve the hydrogen decay time. The MS vacuum system was modified by adding a stainless steel flanged tee, a gate valve, and a room-temperature hydrogen getter downstream from the quadrupole. Under vacuum the gate valve can be opened, exposing the getter to the system to help scavenge hydrogen from the system following analysis. This modification reduced the residence time of hydrogen in the system substantially and decreased the background level of hydrogen by about a factor of 2 . The getter improved the syste response to transient events that might result in the release of hydrogen.

A Granville-Phillips variable leak valve, series 203, was added to the gas sampling inlet of the MS to permit operation over a wide range of system pressures. Without the leak valve, system pressures above about 40 Torr produce too much flow through the MS capillary tube, which overwhelms the turbo pump used to pump down the MS vacuum chamber. Flow through the leak valve can be continuously varied from $0.4 \mathrm{l} / \mathrm{s}$ to $10^{-11} \mathrm{l} / \mathrm{s}$, which allows the MS inlet pressure to be controlled to any pressure desired, even if the system pressure varies dramatically. The pressure on the low-pressure side of the leak valve is measured using a Cole-Parmer sensor (PE-07) and recorded by the DACS. The inlet head pressure is divided by the pressure used for the calibration, and this factor is applied to the test data for calculating actual gas concentrations. The MS was calibrated at $\sim 30$ Torr head pressure with two certified gas standards consisting of 114 and 1050 ppmv hydrogen in argon.

\subsubsection{MTI M200 Gas Chromatograph}

The MTI M200 Gas Chromatograph is a high-speed GC that is used to monitor the quantities of hydrogen and other light gases in the furnace testing system gas loop. This instrument is interfaced with a laptop computer to record data. The GC is designed to operate at near-atmospheric pressure; thus, it may 
be configured in two different ways for measurement purposes. At system pressures near atmospheric, the GC is configured to sample directly from the gas loop ahead of the system vacuum pump. When the system is under vacuum, the GC is configured to sample from the exhaust side of the vacuum pump. The gas output from the pump is sufficiently compressed that the GC can sample and analyze this gas. The GC inlet pressure is measured using a Cole-Parmer pressure sensor (PE-08) and recorded by the DACS. No correction for the difference in the sample pressure and calibration pressure is applied, since both are 760 Torr (1 atm). 'The GC was calibrated using three certified gas standards consisting of 11, 114, and 1050 ppmv hydrogen.

\subsection{Process Instrumentation}

The furnace testing system contains several process instruments for monitoring moisture content, pressure, and temperature. The key instruments are as follows:

- Panametrics moisture monitor

- MKS Baratron pressure transducers

- Cole-Parmer pressure transducers

- Type-K thermocouples.

\subsubsection{Panametrics Moisture Monitor}

The Panametrics moisture monitor model MMS35 uses a solid electrochemical probe (model M2L) that measures moisture by measuring the characteristic capacitance of the probe as a function of the moisture in the gas phase. The sensor has a nominal dew point range of $-110^{\circ} \mathrm{C}$ to $20^{\circ} \mathrm{C}$. Previous testing indicated that contamination causes the probe to lose calibration and results in moisture readings that drift with time. To prevent contamination of the probe tip, the probe is installed in the gas loop downstream of two glass particulate filters. Further, the probes are changed following each test and surveyed for radioactive contamination. If no contamination is found, and the data correlate well with the data obtained from the MS, the readings are accepted.

A calibration verification procedure can be performed using calibrated water "leak" tubes. These tubes can be placed inside the furnace and, when heated, will establish a known water vapor pressure in the system. However, this procedure is time intensive; approximately 2 weeks are required to calibrate one probe over the range of moisture likely to be encountered in these tests. This procedure is only used if the moisture monitor results vary widely from the MS data.

Output of the moisture monitor is in dew point (DP) in degrees Celsius. For comparison with other test data, these dew point values were converted to water vapor pressure in Torr using the water and ice 
vapor pressure data shown in Table 2.1. Interpolation of the data was accomplished using a 6th-order polynomial fit to the log of the vapor pressure (VP) versus temperature data. The resulting conversion expression is as follows:

$$
\mathrm{VP}(\text { Torr })=\log ^{-1}\left[\mathrm{C}_{1} \cdot \mathrm{DP}^{6}+\mathrm{C}_{2} \cdot \mathrm{DP}^{5}+\mathrm{C}_{3} \cdot \mathrm{DP}^{4}+\mathrm{C}_{4} \cdot \mathrm{DP}^{3}+\mathrm{C}_{5} \cdot \mathrm{DP}^{2}+\mathrm{C}_{6} \cdot \mathrm{DP}+\mathrm{C}_{7}\right]
$$

where $C_{1}=-6.7260 \mathrm{E}-12$

$\mathrm{C}_{2}=-1.7250 \mathrm{E}-09$

$\mathrm{C}_{3}=-1.7089 \mathrm{E}-07$

$\mathrm{C}_{4}=-7.2618 \mathrm{E}-06$

$\mathrm{C}_{5}=-2.9668 \mathrm{E}-04$

$\mathrm{C}_{6}=3.4414 \mathrm{E}-02$

$\mathrm{C}_{7}=6.5933 \mathrm{E}-01$

Table 2.1. Water and Ice Vapor Pressure Data Versus Temperature

\begin{tabular}{|c|c|c|c|}
\hline \multirow{2}{*}{$\begin{array}{c}\text { Dew Point } \\
\left({ }^{\circ} \mathbf{C}\right)\end{array}$} & \multicolumn{3}{|c|}{ Vapor Pressure (VP) } \\
\cline { 2 - 4 }$\left(\mathbf{~ P a ) ~}^{(\mathrm{a})}\right.$ & (Torr) & Log (Torr) \\
\hline-80 & $5.500 \mathrm{E}-02$ & $4.126 \mathrm{E}-04$ & $-3.385 \mathrm{E}+00$ \\
-75 & $1.220 \mathrm{E}-01$ & $9.151 \mathrm{E}-04$ & $-3.039 \mathrm{E}+00$ \\
-70 & $2.610 \mathrm{E}-01$ & $1.958 \mathrm{E}-03$ & $-2.708 \mathrm{E}+00$ \\
-65 & $5.400 \mathrm{E}-01$ & $4.051 \mathrm{E}-03$ & $-2.392 \mathrm{E}+00$ \\
-60 & $1.080 \mathrm{E}+00$ & $8.101 \mathrm{E}-03$ & $-2.091 \mathrm{E}+00$ \\
-55 & $2.093 \mathrm{E}+00$ & $1.570 \mathrm{E}-02$ & $-1.804 \mathrm{E}+00$ \\
-50 & $3.936 \mathrm{E}+00$ & $2.952 \mathrm{E}-02$ & $-1.530 \mathrm{E}+00$ \\
-45 & $7.202 \mathrm{E}+00$ & $5.402 \mathrm{E}-02$ & $-1.267 \mathrm{E}+00$ \\
-40 & $1.284 \mathrm{E}+01$ & $9.631 \mathrm{E}-02$ & $-1.016 \mathrm{E}+00$ \\
-35 & $2.235 \mathrm{E}+01$ & $1.676 \mathrm{E}-01$ & $-7.756 \mathrm{E}-01$ \\
-30 & $3.801 \mathrm{E}+01$ & $2.851 \mathrm{E}-01$ & $-5.450 \mathrm{E}-01$ \\
-25 & $6.329 \mathrm{E}+01$ & $4.747 \mathrm{E}-01$ & $-3.235 \mathrm{E}-01$ \\
-20 & $1.033 \mathrm{E}+02$ & $7.746 \mathrm{E}-01$ & $-1.109 \mathrm{E}-01$ \\
-15 & $1.653 \mathrm{E}+02$ & $1.240 \mathrm{E}+00$ & $9.339 \mathrm{E}-02$ \\
-10 & $2.599 \mathrm{E}+02$ & $1.950 \mathrm{E}+00$ & $2.899 \mathrm{E}-01$ \\
-5 & $4.018 \mathrm{E}+02$ & $3.014 \mathrm{E}+00$ & $4.791 \mathrm{E}-01$ \\
0 & $6.113 \mathrm{E}+02$ & $4.585 \mathrm{E}+00$ & $6.614 \mathrm{E}-01$ \\
10 & $1.228 \mathrm{E}+03$ & $9.212 \mathrm{E}+00$ & $9.644 \mathrm{E}-01$ \\
\hline
\end{tabular}

\subsubsection{MKS Baratron Pressure Transducers}

Two MKS Baratron model 690 calibrated pressure transducers coupled with MKS model 270 signal conditioners are used as the primary measurement for the overall system pressure. As shown in Figure 2.3, PE-01 measures the system pressure downstream of the retort outlet, whereas PE-06 measures the system pressure at the retort inlet. PE- 01 indicates pressure in the range of 0.1 Torr to 10,000 Torr. 
The pressure range of PE-06 is 0.01 Torr to 1000 Torr. PE-06 was installed after the first two fuel element drying tests to provide more accurate measurements than PE-01 for low pressures. PE-06 is therefore considered the primary system pressure measurement. In addition, the 270 signal conditioner procured with PE-06 has a special capability to remotely zero the transducer, which provides more accurate pressure measurements below 1 Torr.

An auxiliary high vacuum turbo pump is used to evacuate the inlet to PE-06 to well below $10^{-4}$ Torr so that the transducer can be accurately re-zeroed. The 270 signal conditioner used with PE- 01 does not have a remote zeroing capability. Both signal conditioners have analog outputs that are interfaced to the DACS so that system pressure is continuously recorded.

\subsubsection{Cole-Parmer Pressure Transducers}

Two Cole-Parmer model H-68801-53 calibrated diaphragm-type, calibrated pressure transducers are installed on the MS and GC sample lines as indicated by PE-07 and PE-08 in Figure 2.3. These pressure measurements are used to normalize the MS and GC data so that actual gas concentrations in the syste can be calculated from the relative concentrations measured. These sensors have a range of 0 to 1500 Torr with a resolution of 0.1 Torr and an accuracy of $\pm 1 \%$ or \pm 1 Torr, whichever is larger. Both readout units (model H-68801-03) have analog outputs that are interfaced to the DACS so that these pressures are continuously recorded.

\subsubsection{Thermocouples}

Thermocouples provide a simple, reliable method for measuring system temperatures. As shown in Figure 2.3, over 20 thermocouples are installed at various locations in the system to provide key temperature measurements. The retort temperatures are of primary importance, and these temperatures are measured by thermocouples TE-04 through TE-10, which are positioned equidistant along the length of the retort. Other key temperature measurements include the retort center temperature (TE-20, which is a 30-in.-long thermocouple installed through the outlet end of the retort); retort inlet temperature (TE-21); condenser gas temperature (TE-19); and the condenser coolant temperature (TE-22). Thermocouples TE-11 through TE-17 are used for controlling the temperature of the heated lines. All thermocouple readings are continuously recorded using the DACS.

\subsection{Data Acquisition and Control System}

The DACS monitors system parameters and controls the furnace and the safety argon system. The DACS consists of a Hewlett Packard (HP) 3497A data acquisition/control unit, and an IBM-compatible computer. A National Instruments general purpose interface bus card, installed in the IBM-compatible computer, is used to communicate with the HP 3497A. The computer communicates with the furnace temperature controllers over serial port 0 using an RS-232/RS-485 converter. The DACS uses National Instruments LabView for Windows as the control software. 
The DACS is designed to measure critical system parameters during fuel conditioning tests, including temperatures, pressures, flow rates, and moisture level. The measured parameters are converted to engineering units, displayed on the computer screen, and stored to disk at user-defined intervals. The data files are stored in a tab-delimited format to allow importing into a standard spreadsheet or plotting program. A plotting screen also allows for plotting of up to six parameters at a time.

Limited control of the furnace can be performed with the DACS. Each of the three furnace zone temperatures can be remotely set by the DACS. In addition, the DACS allows the operator to start and stop the furnace and select one of four temperature profiles that are pre-programmed in the furnace temperature controllers. Note that these profiles must be programmed manually in the furnace controllers before using the DACS to select them. 


\subsection{Vacuum Drying Testing of Element 2660M}

The drying test was performed in accordance with Test Procedure, Furnace Testing of N-Reactor Fuel Element 2660M, PTL-007, Revision 0. This document is located in the PNNL permanent project records for this test.

The testing consisted of three parts (discussed in this section):

- removing the fuel from its shipping canister, performing a visual inspection, loading the fuel onto the furnace system sample boat, and transferring it to the PTL G-Cell for loading into the furnace.

- drying the fuel element using a combination of Cold Vacuum Drying (CVD) and Hot Vacuum Drying (HVD) processes.

- unloading the furnace, performing a post-test visual inspection, and returning the fuel element to its shipping canister.

\subsection{Fuel Element Transfer and Loading}

\subsubsection{Pre-Test Visual Inspection}

The pre-test visual inspection was conducted using a high-resolution color CCD video camera located inside the PTL F-Cell (adjacent to the G-Cell), where the sample was unloaded from the shipping canister and visually inspected. The results were recorded using a Panasonic Super-VHS resolution video recorder. This examination was conducted to document the condition of the fuel element before the test and to determine if any changes had occurred since it was removed from the K-West Basin and shipped to the PTL. The results of this inspection are presented in Section 4.0.

\subsubsection{Fuel Element Rinsing}

Fuel element $2660 \mathrm{M}$ had been stored in the PTL water storage pool contained in a single fuel element canister (SFEC) that was filled with K-Basin water. Before the start of the drying test, the element was rinsed in F-Cell. This rinsing involved raising and lowering the element several times in the SFEC using one of the cell's manipulators. Following rinsing, the element was transferred to G-Cell for loading into the element test retort. 


\subsection{Fuel Element Drying}

The fuel element was subjected to cold and hot vacuum drying. The drying test was conducted in six phases:

1. Cold Vacuum Drying

2. Pressure Rise Test

3. Hot Vacuum Drying (first step)

4. Hot Vacuum Drying (second step)

5. Hot Vacuum Drying (third step)

6. Post-Test Pressure Rise Test

The nominal design conditions used for these test phases are summarized in Table 3.1. Each phase is discussed below.

Table 3.1. Summary of Nominal Test Design Conditions

\begin{tabular}{|c|c|}
\hline Test Segment & Nominal Test Condition $^{(a)}$ \\
\hline $\begin{array}{l}\text { A. Cold Vacuum Drying } \\
\text { System Configuration } \\
\text { Test Temperature, }{ }^{\circ} \mathrm{C} \\
\text { Atmosphere } \\
\text { Pressure, Torr } \\
\text { Gas Flow Rate, cc/min } \\
\text { Gas Species Monitored } \\
\text { Duration, hr }\end{array}$ & 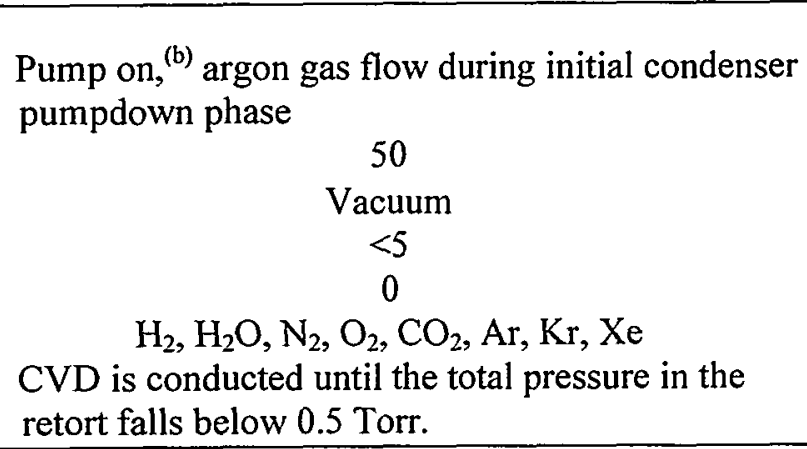 \\
\hline $\begin{array}{l}\text { B. Pressure Rise Test } \\
\text { System Configuration } \\
\text { Test Temperature, }{ }^{\circ} \mathrm{C} \\
\text { Atmosphere } \\
\text { Initial Pressure, Torr } \\
\text { Gas Flow Rate, cc/min } \\
\text { Gas Species Monitored } \\
\text { Pressure Rise (acceptable level, Torr) } \\
\text { Duration, hr } \\
\end{array}$ & $\begin{array}{c}\text { Test Chamber Isolated } \\
50 \\
\text { Vacuum } \\
<5 \\
0 \\
\mathrm{H}_{2}, \mathrm{H}_{2} \mathrm{O}, \mathrm{N}_{2}, \mathrm{O}_{2}, \mathrm{CO}_{2}, \mathrm{Ar}, \mathrm{Kr}, \mathrm{Xe} \\
<0.5 \\
1\end{array}$ \\
\hline $\begin{array}{l}\text { C. Hot Vacuum Drying (Step 1) } \\
\text { System Configuration } \\
\text { Test Temperature Range, }{ }^{\circ} \mathrm{C} \\
\text { Atmosphere } \\
\text { Pressure, Torr } \\
\text { Gas Flow Rate, cc/min } \\
\text { Gas Species Monitored } \\
\text { Duration, hr }\end{array}$ & $\begin{array}{c}\text { Pump on, }{ }^{(b)} \text { argon gas flow } \\
75 \\
\text { Vacuum, Ar background } \\
15 \\
300 \\
\mathrm{H}_{2}, \mathrm{H}_{2} \mathrm{O}, \mathrm{N}_{2}, \mathrm{O}_{2}, \mathrm{CO}_{2}, \mathrm{Ar}, \mathrm{Kr}, \mathrm{Xe} \\
24\end{array}$ \\
\hline
\end{tabular}


Table 3.1. (contd)

\begin{tabular}{|c|c|}
\hline Test Segment & Nominal Test Condition $^{\left({ }^{(a)}\right.}$ \\
\hline D. Hot Vacuum Drying (Step 2) & \\
\hline System Configuration & Pump on, ${ }^{(b)}$ argon gas flow \\
\hline Test Temperature Range, ${ }^{\circ} \mathrm{C}$ & 75 to 400 \\
\hline Temperature Ramp Rate, ${ }^{\circ} \mathrm{C} / \mathrm{hr}$ & 10 \\
\hline Atmosphere & Vacuum, Ar background \\
\hline Pressure, Torr & 15 \\
\hline Gas Flow Rate, cc/min & 300 \\
\hline Gas Species Monitored & $\mathrm{H}_{2}, \mathrm{H}_{2} \mathrm{O}, \mathrm{N}_{2}, \mathrm{O}_{2}, \mathrm{CO}_{2}, \mathrm{Ar}, \mathrm{Kr}, \mathrm{Xe}$ \\
\hline Duration, $\mathrm{hr}$ & 35 \\
\hline E. Hot Vacuum Drying (Step 3) & \\
\hline System Configuration & Pump on, ${ }^{(b)}$ argon gas flow \\
\hline Test Temperature, ${ }^{\circ} \mathrm{C}$ & 400 \\
\hline Atmosphere & Vacuum, Ar background \\
\hline Pressure, Torr & 15 \\
\hline Gas Flow Rate, cc/min & 300 \\
\hline Gas Species Monitored & $\mathrm{H}_{2}, \mathrm{H}_{2} \mathrm{O}, \mathrm{N}_{2}, \mathrm{O}_{2}, \mathrm{CO}_{2}, \mathrm{Ar}, \mathrm{Kr}, \mathrm{Xe}$ \\
\hline Duration, hr & 10 \\
\hline F. Cooldown & \\
\hline System Configuration & Pump on, ${ }^{(b)}$ argon gas flow \\
\hline Test Temperature, ${ }^{\circ} \mathrm{C}$ & 400 to 50 \\
\hline Atmosphere & Vacuum \\
\hline Initial Pressure, Torr & 15 \\
\hline Gas Flow Rate, cc/min & 300 \\
\hline Gas Species Monitored & $\mathrm{H}_{2}, \mathrm{H}_{2} \mathrm{O}, \mathrm{N}_{2}, \mathrm{O}_{2}, \mathrm{CO}_{2}, \mathrm{Ar}, \mathrm{Kr}, \mathrm{Xe}$ \\
\hline \begin{tabular}{|l|} 
Duration, hr \\
G. Pressure Rise Test
\end{tabular} & 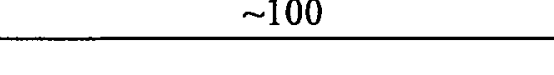 \\
\hline System Configuration & Test Chamber Isolated \\
\hline Test Temperature, ${ }^{\circ} \mathrm{C}$ & 50 \\
\hline Atmosphere & Vacuum \\
\hline Initial Pressure, Torr & $<5$ \\
\hline Gas Flow Rate, cc/min & 0 \\
\hline $\begin{array}{l}\text { Gas Species Monitored } \\
\text { Duration, } \mathrm{hr}\end{array}$ & $\mathrm{H}_{2}, \mathrm{H}_{2} \mathrm{O}, \mathrm{N}_{2}, \mathrm{O}_{2}, \mathrm{CO}_{2}, \mathrm{Ar}, \mathrm{Kr}, \mathrm{Xe}$ \\
\hline
\end{tabular}

\subsubsection{Cold Vacuum Drying}

While the fuel element was being handled and prepared for the drying test, it was kept damp by sprinkling it with deionized water. The amount of surplus liquid water, though small, could not be ascertained. There were no pools of water in the sample boat; however, water was adsorbed onto corroded areas, cracks, and crevices. An additional $\sim 10 \mathrm{ml}$ of water were added to the sample boat just before loading it into the furnace to ensure sufficient free water in the system prior to CVD. 
The furnace was first purged with argon to remove as much air as possible. The furnace was then isolated and the furnace temperature increased to approximately $50^{\circ} \mathrm{C}$ and allowed to stabilize. After stabilization, argon flow was re-established; the system vacuum pump was turned on (in a throttled mode); and the system water condenser was valved in. When the system pressure became lower than the condenser could extract, the condenser was valved out of the gas loop and the argon flow stopped. The remainder of the CVD was conducted with the throttled vacuum pump. CVD was conducted at an ultimate pressure of $\sim 0.2$ Torr for $\sim 16 \mathrm{hr}$. The purpose of the CVD portion of the test was to determine if CVD is successful in removing the majority of the free water from the system in a reasonable length of time.

\subsubsection{Pressure Rise Test}

The Pressure Rise Test involved isolating the system and measuring any pressure increase while at CVD pressure and temperature conditions. The purpose of the Pressure Rise Test was to determine the effectiveness of the preceding CVD process. This test was conducted by valving the vacuum pump out of the gas loop and closing the exhaust valves. The condition for acceptance of this portion of the test was a total system pressure rise of less than 0.5 Torr in a 1-hr time period. If this condition was not met, the system was re-opened to the vacuum pump and the Pressure Rise Test repeated.

\subsubsection{Hot Vacuum Drying, Step 1}

Following completion of the Pressure Rise Test, the vacuum pump was re-opened to the system retort; argon gas flow was established at a rate of $\sim 324 \mathrm{cc} / \mathrm{min}$; and the retort temperature was increased to $\sim 76^{\circ} \mathrm{C}$. This condition was held for a period of $\sim 25 \mathrm{hr}$. This portion of the test can be used to obtain isothermal hydrogen and water release data for assessing oxidation of the fuel at low temperatures.

\subsubsection{Hot Vacuum Drying, Step 2}

The second step of the HVD process involved raising the temperature of the retort from $\sim 75^{\circ} \mathrm{C}$ to $\sim 400^{\circ} \mathrm{C}$ at a carefully controlled rate while maintaining the same argon flow and pressure conditions. Thus, any release of gas species during this temperature rise could be assigned to a specific temperature. The second step of HVD was conducted for about $35 \mathrm{hr}$.

During this step, hydrogen may be released from the fuel through the decomposition of uranium hydride (Cotton 1988); this reaction is rapid at temperatures greater than $250^{\circ} \mathrm{C}$ :

$$
\mathrm{UH}_{3} \rightarrow \mathrm{U}+\frac{3}{2} \mathrm{H}_{2}
$$

Water may also be liberated by various hydrated species found on fuel elements, such as hydrates of

uranium oxides, aluminum hydroxides, and hydrated iron oxides. Water is also released slowly along a "tortuous path" from beneath corroded parts of the fuel element and from behind the cladding. The released water can react with the fuel element to generate hydrogen through the reactions: 


$$
\begin{gathered}
\mathrm{U}+2 \mathrm{H}_{2} \mathrm{O} \rightarrow \mathrm{UO}_{2}+2 \mathrm{H}_{2} \\
\mathrm{UH}_{3}+2 \mathrm{H}_{2} \mathrm{O} \rightarrow \mathrm{UO}_{2}+\frac{7}{2} \mathrm{H}_{2}
\end{gathered}
$$

\subsubsection{Hot Vacuum Drying, Step 3}

The final step of the HVD process involved holding the temperature of the retort at $\sim 400^{\circ} \mathrm{C}$ while again maintaining the same argon flow and pressure conditions as in steps 1 and 2 . This step will yield isothermal release data for any remaining hydrated species on the fuel element and for oxidation of uranium by any remaining water. This final step of the HVD process was conducted for about $10 \mathrm{hr}$.

\subsubsection{System Cooldown and Post-Tèst Pressure Rise Test}

Following completion of the final HVD step, the system retort was allowed to cool to $\sim 50^{\circ} \mathrm{C}$ while maintaining the same vacuum and flow conditions, and then another Pressure Rise Test was conducted to determine the baseline in-leakage rate of air into the retort from the cell environment. Knowing this rate is important to allow for correction of the system and moisture pressure increase rates determined in the initial post-CVD Pressure Rise Test. Since the conditions for the post-HVD test are identical to those used for the initial test, the assumption is made that the air in-leakage rate should be nearly the same as well.

\subsection{Calculation of Water and Hydrogen Inventories}

Assuming ideal gas behavior of the water vapor, total water inventory $(\mathrm{m})$ in the system during those portions of the test conducted with argon flowing into the retort can be approximated from the measured water vapor pressure and the argon gas flow as follows:

$$
\frac{d \mathrm{~m}}{d \mathrm{t}}=\frac{\mathrm{M}}{\mathrm{V}_{0}} \cdot \frac{\mathrm{P}_{\mathrm{w}}}{\left(\mathrm{P}_{\mathrm{t}}-\mathrm{P}_{\mathrm{w}}\right)} \cdot \frac{d \mathrm{~V}}{d \mathrm{t}}
$$

where $d \mathrm{~m} / d t$ is the rate of water removal in grams per minute, $\mathrm{M}$ is the molecular mass of water in grams per mole, $d \mathrm{~V} / d t$ is the flow rate in liters per minute (at the calibration temperature of $25^{\circ} \mathrm{C}$ ), $\mathrm{V}_{0}$ is the molar volume of gas at $25^{\circ} \mathrm{C}$ and 1 atmosphere in liters per mole, $\mathrm{P}_{\mathrm{w}}$ is the partial pressure of water vapor in Torr, and $\mathrm{P}_{\mathrm{t}}$ is the total pressure in Torr. The total amount of water released is given by integrating the rate data over time.

The hydrogen inventory may be calculated in a similar fashion with the $\left[\mathrm{P}_{w} /\left(\mathrm{P}_{\mathrm{t}}-\mathrm{P}_{\mathrm{w}}\right)\right]$ expression in the above equation replaced with the measured atom fraction of hydrogen. For the purposes of this report, all hydrogen data are plotted in Torr-l rather than grams. At the calibration conditions of the argon flow controller, 1 Torr 1 is equivalent to approximately $0.11 \mathrm{mg}$ of hydrogen. 
The assumptions made in estimating the water and hydrogen values are:

- The flow into the retort is approximately equal to the flow out (i.e., contributions to the flow from other gas species such as hydrogen are neglected).

- The argon mass flow is referenced to $25^{\circ} \mathrm{C}$ (as determined from the calibration of the flow gauges).

- The sample gas is at the same temperature as the calibration gas (GC and MS measurements). 


\subsection{Visual Examinations of Element 2660M}

An N-Reactor fuel assembly consists of an inner element and outer element made from a uraniu alloy co-extruded with a Zircaloy-2 cladding. Both elements are annular, right-cylinders. The inner element has a smaller outer diameter and is held in place within the outer element.

Fuel element 2660M, chosen for Run 7, was an outer element removed from the K-West Basin in 1996. The element had been in sealed water storage in the $\mathrm{K}$-West Basin since 1983. This fuel element was selected to represent a classification of fuel damage termed "severely damaged" (Lawrence 1997). The furnace drying test series (of which this is Run 7 of 8) were intended to progress from intact (unbreached) fuel elements to severely damaged fuel elements. This fuel element, therefore, was to represent a fuel element that falls at the upper end of the damage spectrum.

The fuel element had been kept in K-Basin water at the PTL storage basin since it was loaded into its SFEC and shipped to the facility in 1996. The first relatively detailed examination of the fuel element was conducted just before the drying test and is discussed below.

\subsection{Pre-Test Visual Examination}

The fuel element was removed from its SFEC and examined using a CCD color video camera in the PTL F-Cell. The fuel element was split along the length in several places. One end of the fuel element was breached, and the fuel was corroded and partly missing. Figure 4.1 is a full-length photomosaic of still images captured from the pre-test visual examination video. The individual images do not completely line up, as the camera motion was controlled only by a remote slave-manipulator that does not allow precise motion. However, the extent of the fuel damage is apparent. Figure 4.2 is a photomosaic of still images showing a longitudinal split in the fuel cladding. This cladding split is on the other side of the fuel element view shown in Figure 4.1.

Similar to several of the other fuel elements used in previous tests, this element appeared to have a thin, light-gray-colored coating on the surface. No attempt was made to recover this material, as experience has shown that a large amount of surface would have to be "scrubbed" to gather an adequate sample for analysis. As the surface of the fuel element dried during the visual examination, cracks became more visible due to water wicking up from the interior of those cracks.

\subsection{Post-Test Visual Examination}

Similar to the fuel elements tested in Runs 4 (Element 5744U), 5 (Element 6603M), and 6 (Element $1164 \mathrm{M}$ ), the fuel element surface coloration changed from a light gray color to a dark color. As discussed in the results from those tests, this could be due to the transformation of uranium oxy-hydrates releasing water and leaving behind simpler oxide phases. Some oxides are known to be dark in color, as observed on the fuel element. 


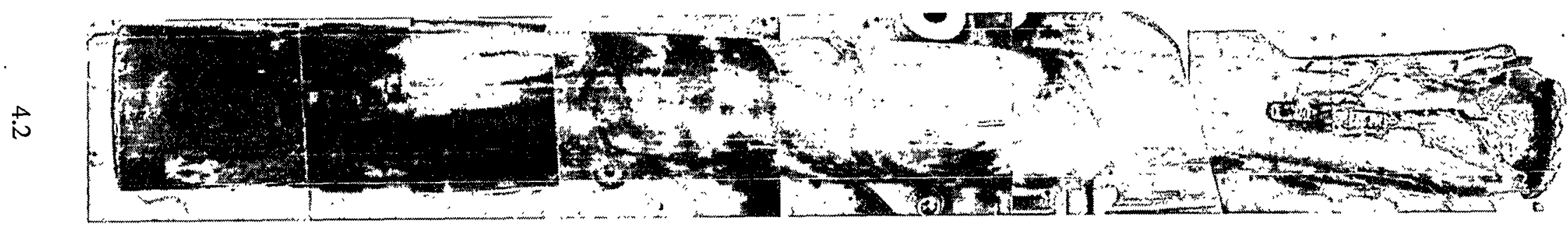

Figure 4.1. Photomosaic of Element 2660M 


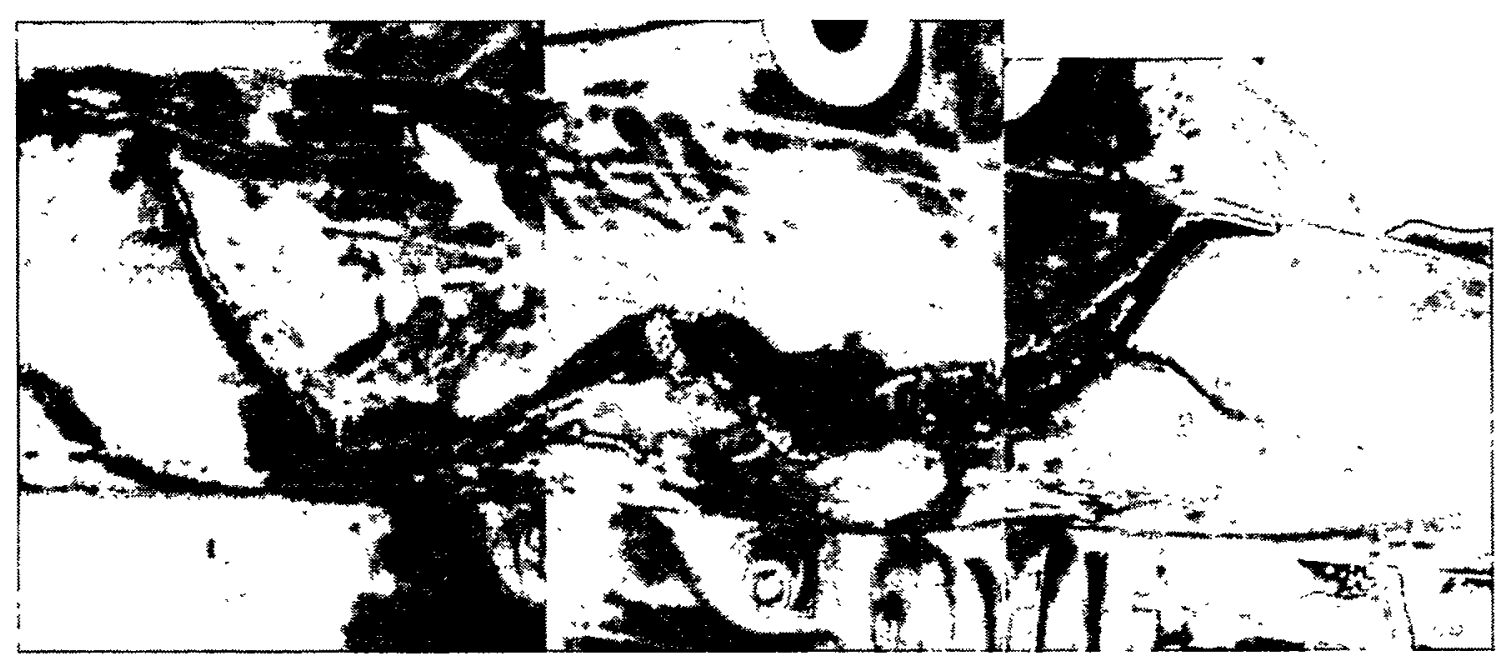

Figure 4.2. Photomosaic of a Large Longitudinal Crack on Element 2660M. The uranium fuel matrix is visible as the dark gray area inside the crack.

Similar to other tests, the fuel element cracks broadened as a result of the drying test. The drying process used for this test, as in all the tests conducted for this test series, involved several stages and included a step during which the fuel element was heated to $400^{\circ} \mathrm{C}$. It is uncertain during which stage the cladding cracks opened further. It was possible to view the fuel matrix under the cladding cracks in many places. The fuel matrix appeared similar to Elements $5744 \mathrm{U}$ and $6603 \mathrm{M}$ from Runs 4 and 5, respectively. It did not appear "rubbleized" as was observed for Element 1164M tested in Run 6.

Figure 4.3 shows a view of a crack that had opened significantly during the drying test. Although many of the cracks opened further during drying, the fuel matrix beneath those cracks did not always appear to be significantly oxidized (as shown in Figure 4.3). It may be possible that the heating to $400^{\circ} \mathrm{C}$ during the final water-removal drying cycle could have been sufficient to relieve residual strain in cladding, resulting in the cladding "leaves" opening up. Figure 4.4 shows an additional view of a crack that had opened up during drying. A piece of fuel that was loose can be seen wedged under the cladding near the center of the crack in this view. Although some small pieces of fuel material fell out from this crack, the uranium matrix appears relatively intact despite of the major cladding failure.

Figure 4.5 shows some of the particulates that fell from Element 2660M during the post-test visual examination. These particulates are more powder-like than those recovered from Element 1164M dried in Run 6. These particulates have been collected and archived for future analyses (if required).

The results of the visual examination of Element $2660 \mathrm{M}$ suggest that the uranium fuel matrix is similar to those elements tested in Runs 4 and 5, Elements 5744U and 6603, respectively. The rubbleized appearance of Element 1164M tested in Run 6 was not observed on this fuel element. Therefore, although this fuel element may be classified as "severely damaged," it may not actually be so severe in terms of overall fuel surface area, or percentage of cracks, which are postulated to hold much of the uranium hydride inventory. 


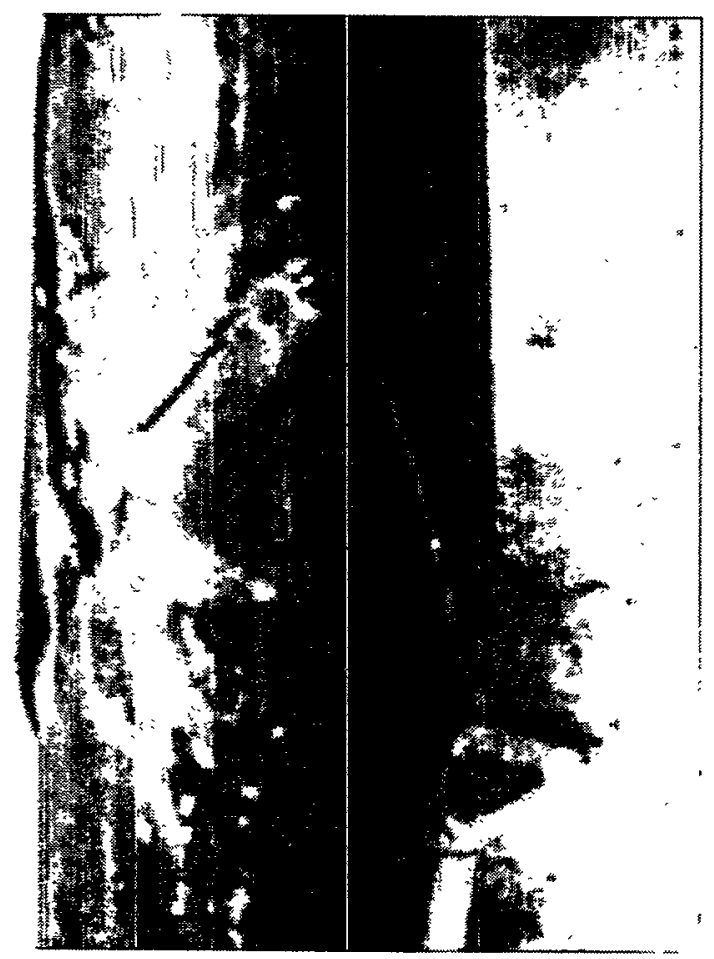

Figure 4.3. Post-Test View of a Crack in Element 2600M That Opened Significantly During the Drying Test

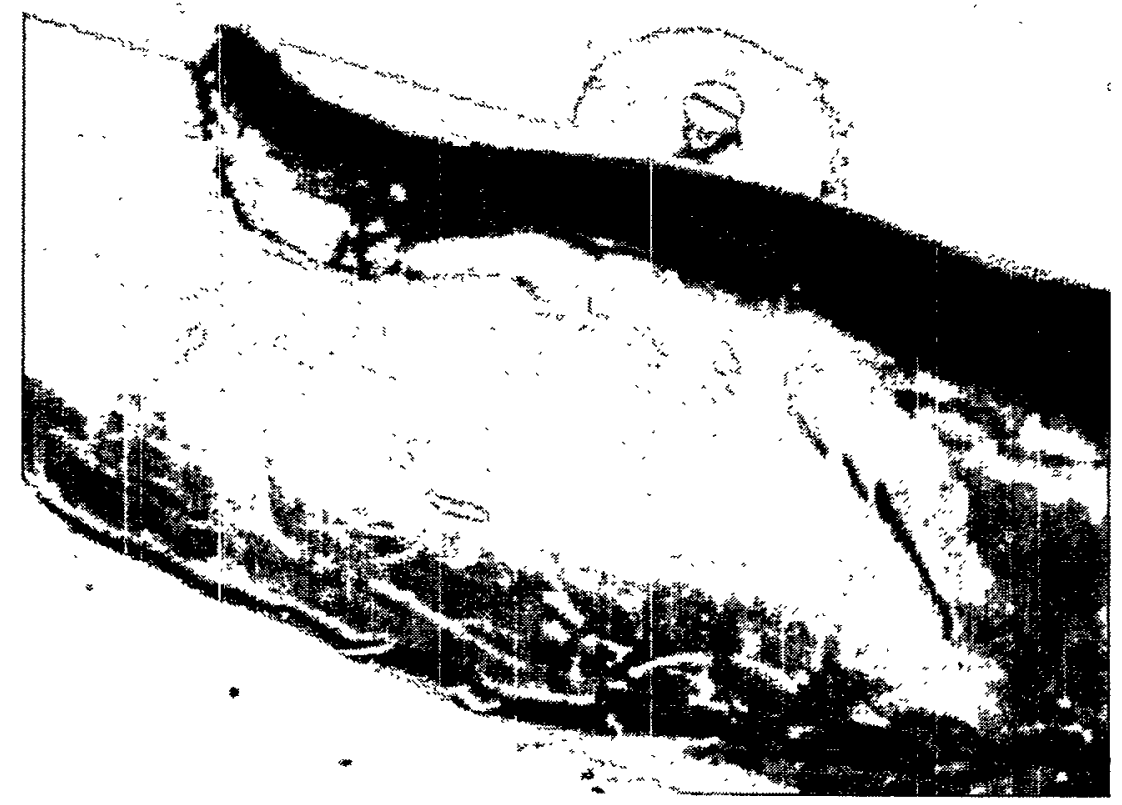

Figure 4.4. View of an Additional Crack That Opened During Drying. A piece of fuel that was loose can be seen wedged under the cladding near the center of the crack. 


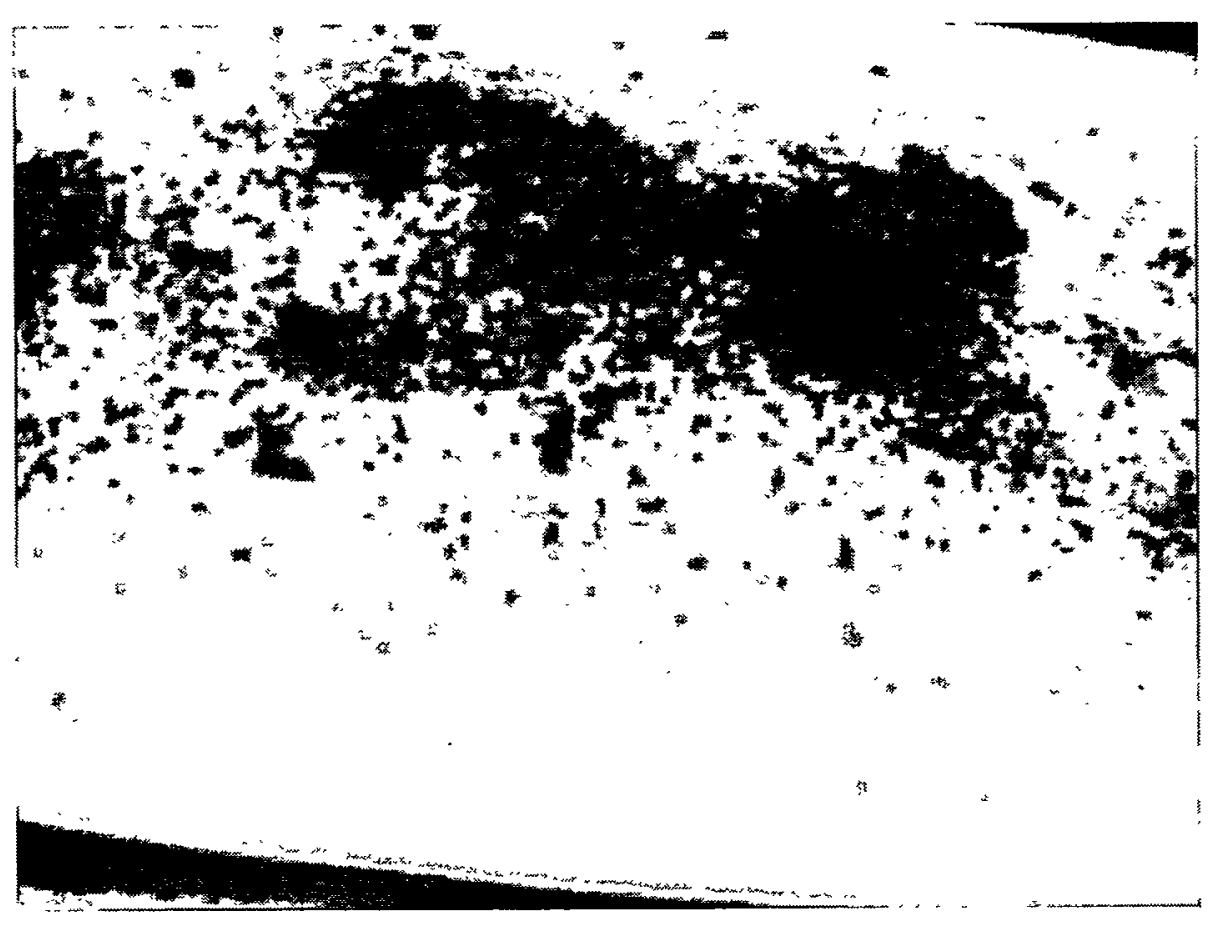

Figure 4.5. Powder-Like Particulates Recovered During the Post-Test Visual Examination of Element $2660 \mathrm{M}$ 


\subsection{Experimental Results}

In the following sections, the experimental data collected during the drying test are expanded and plotted for each segment. Summary results from the test are plotted in Figure 5.1. This figure shows the system moisture-level response to the pressure changes and the retort tube temperatures during the test. Time intervals for the various test segments are shown in the upper section of the plot and are also outlined in Table 5.1. The temperatures shown in Figure 5.1 were recorded from one of seven thermocouples (TE-07) on the system located near the center of the retort. The pressure data were taken from the 0 to 1000 Torr Baratron sensor (PE-06) located upstream of the retort.

\subsection{Cold Vacuum Drying}

The water release from the CVD portion of the test is shown in Figure 5.2. The baseline moisture partial pressure in the system before heating was $\sim 12$ Torr at a retort temperature of $\sim 21^{\circ} \mathrm{C}$. Total system pressure was $\sim 740$ Torr, with no argon gas flow. After heating to $\sim 50^{\circ} \mathrm{C}$, the moisture pressure and system pressure stabilized at $\sim 10$ Torr and $\sim 836$ Torr, respectively. Assuming ideal gas behavior, the pressure after heating is approximately 23 Torr higher than expected. This excess pressure has been observed in all the previous tests, except for the first dry-run, and may have been due to gases evolved during the heatup, such as hydrogen from moisture reactions, and gases dissolved in the free water. Another explanation for the calculated pressure difference is that the average retort temperature was somewhat greater than $50^{\circ} \mathrm{C}$.

The CVD phase started at an elapsed time (ET) of $297 \mathrm{~min}$. Figure 5.2 shows that the moisture pressure rose almost immediately to $\sim 14$ Torr and "saturated" at this pressure for about $75 \mathrm{~min}$. This saturation behavior has been observed in previous tests and is a result of the dew point exceeding the maximum of $20^{\circ} \mathrm{C}$ for the Panametrics moisture probe. At an ET of $\sim 589 \mathrm{~min}$, argon flow was stopped, and the condenser was valved out. Pumping was continued by the throttled vacuum pump. By the end of CVD $(E T=1393 \mathrm{~min}$ ), the moisture pressure had dropped to $\sim 0.6$ Torr, whereas the total pressure was indicating a slightly lower value at $\sim 0.5$ Torr. The reason for this apparent discrepancy is not clear, but may indicate the inherent combined accuracies of the Baratron and Panametrics sensors. This discrepancy was also observed in the two previous drying tests (Runs 5 and 6).

Approximately $15 \mathrm{ml}$ of water were observed in the condenser during the CVD phase. Calculated water removal (from Equation 3.4) during the time period when the condenser was open under argon flow, however, yielded a value of $\sim 13 \mathrm{~g}$, in reasonable agreement with the observed water in the condenser. Approximately $10 \mathrm{ml}$ of water were added at the start of the test, in addition to any water remaining on the element from the initial element rinsing, to ensure the element was damp at the beginning of the test. 


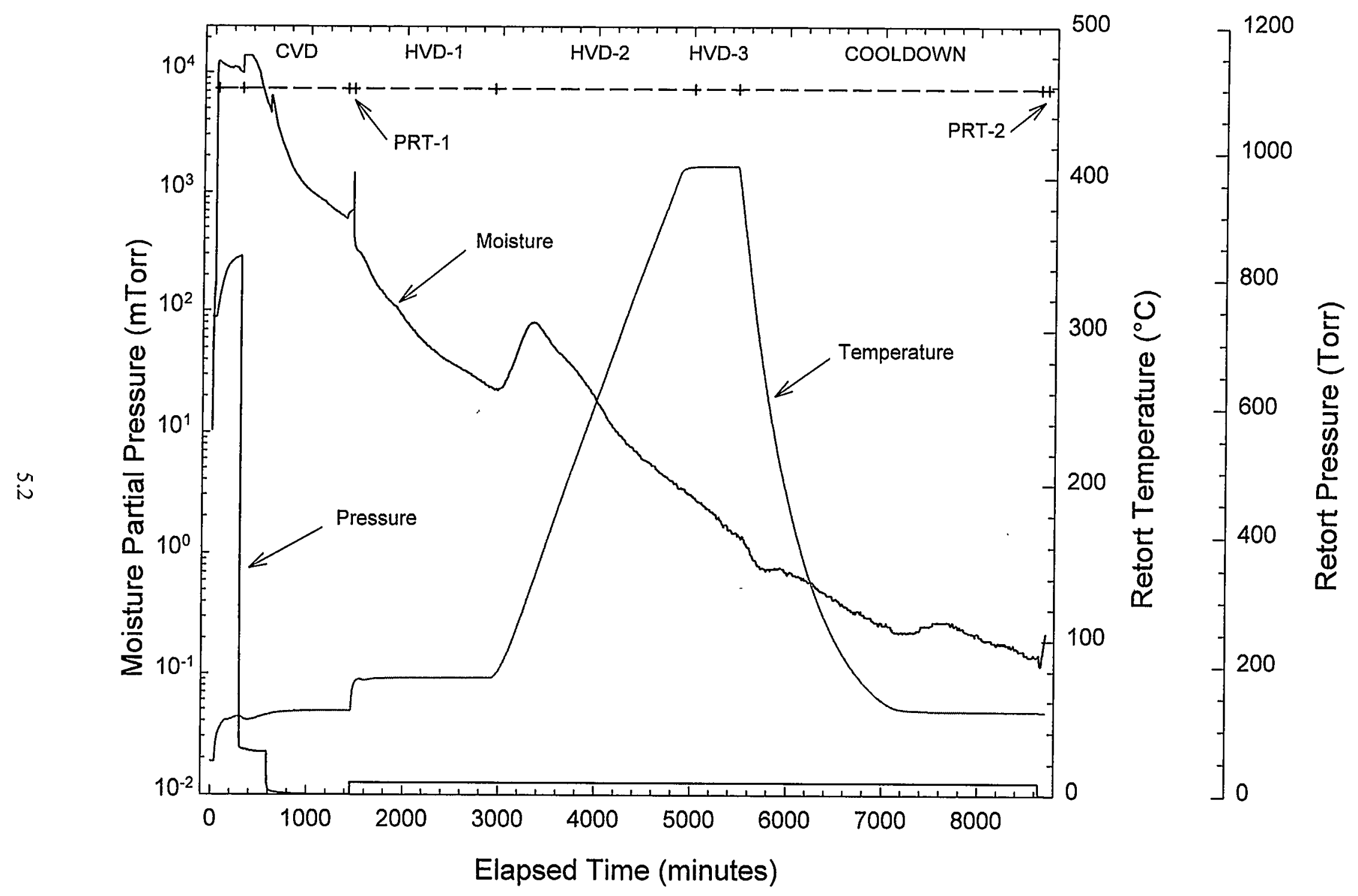

Figure 5.1. Drying of SNF Element 2660M, Summary Plot 
Table 5.1. Fuel Element 2660M Drying Run Time Line

\begin{tabular}{|c|c|c|}
\hline Activity & Date/Time & $\begin{array}{l}\text { Elapsed Time } \\
\text { (min) }\end{array}$ \\
\hline $\begin{array}{l}\text { Start of Test } \\
\text { Heat furnace to } \sim 50^{\circ} \mathrm{C}\end{array}$ & $02 / 03 / 98 \quad 10: 58$ & 43 \\
\hline $\begin{array}{l}\text { Cold Vacuum Drying Test } \\
\text { Open pump }{ }^{(a)} \text { and condenser (initial), start argon flow } \\
\text { Open pump, close condenser (final), stop argon flow }\end{array}$ & 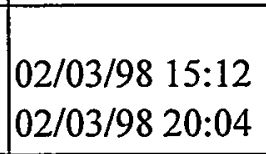 & $\begin{array}{l}297 \\
589\end{array}$ \\
\hline $\begin{array}{l}\text { Pressure Rise Test } \\
\text { Close pump (isolate furnace) } \\
\text { Open pump valve }\end{array}$ & $\begin{array}{ll}02 / 04 / 98 & 09: 28 \\
02 / 04 / 98 & 10: 29\end{array}$ & $\begin{array}{l}1393 \\
1455\end{array}$ \\
\hline $\begin{array}{l}\text { Hot Vacuum Drying Test (Step 1) } \\
\text { Start argon flow }(\sim 320 \mathrm{cc} / \mathrm{min}) \text {, raise furnace temperature to } \\
\sim 80^{\circ} \mathrm{C} \text { and hold }\end{array}$ & $02 / 04 / 98 \quad 10: 30$ & 1456 \\
\hline $\begin{array}{l}\text { Hot Vacuum Drying Test (Step 2) } \\
\text { Raise furnace temperature to } \sim 400^{\circ} \mathrm{C} @ 10^{\circ} \mathrm{C} / \mathrm{min}\end{array}$ & 02/05/98 11:01 & 2926 \\
\hline $\begin{array}{l}\text { Hot Vacuum Drying Test (Step 3) } \\
\text { Hold furnace temperature at } \sim 400^{\circ} \mathrm{C}\end{array}$ & 02/06/98 21:48 & 5014 \\
\hline $\begin{array}{l}\text { System Cooldown } \\
\text { Reduce temperature of retort to } \sim 50^{\circ} \mathrm{C} \text {, maintain argon flow }\end{array}$ & 02/07/98 05:26 & 5471 \\
\hline $\begin{array}{l}\text { Post-Test Pressure Rise Test } \\
\text { Turn off argon flow, and close pump valve (isolate furnace) } \\
\text { Turn off furnace heaters, end test }\end{array}$ & $\begin{array}{ll}02 / 09 / 98 & 10: 25 \\
02 / 09 / 98 & 11: 25\end{array}$ & $\begin{array}{l}8651 \\
8711\end{array}$ \\
\hline
\end{tabular}

\subsection{Pressure Rise Tests}

The results of the two pressure rise phases of the drying test (post-CVD and post-HVD) are shown in Figures 5.3 and 5.4. As discussed earlier, the purpose of the post-HVD test was to determine as best as possible the ambient air in-leakage rate into the system as it had been configured for the drying test. While under vacuum conditions, with no argon flow, any air in-leakage will contribute to the data signals observed for the various process gases measured during the test, particularly water and hydrogen (from oxidation). The data plotted for the total pressure are from the 0 to 1000 Torr Baratron sensor (PE-06) located upstream of the retort. This sensor has higher sensitivity and lower noise than the 0 to 10,000 Torr Baratron (PE-01) located downstream of the retort. To calculate the total water mass removed from the retort, however, pressure data from the 0 to 10,000 Torr sensor (PE-01) were used, as the moisture sensor was also located on the downstream side of the retort. During argon flow conditions, the pressure drop across the retort was $\sim 4$ Torr.

The post-CVD Pressure Rise Test was conducted over an ET of $1393 \mathrm{~min}$ to $1455 \mathrm{~min}$. Both the total pressure and the moisture pressure showed nearly linear pressure rises over the course of the test. 

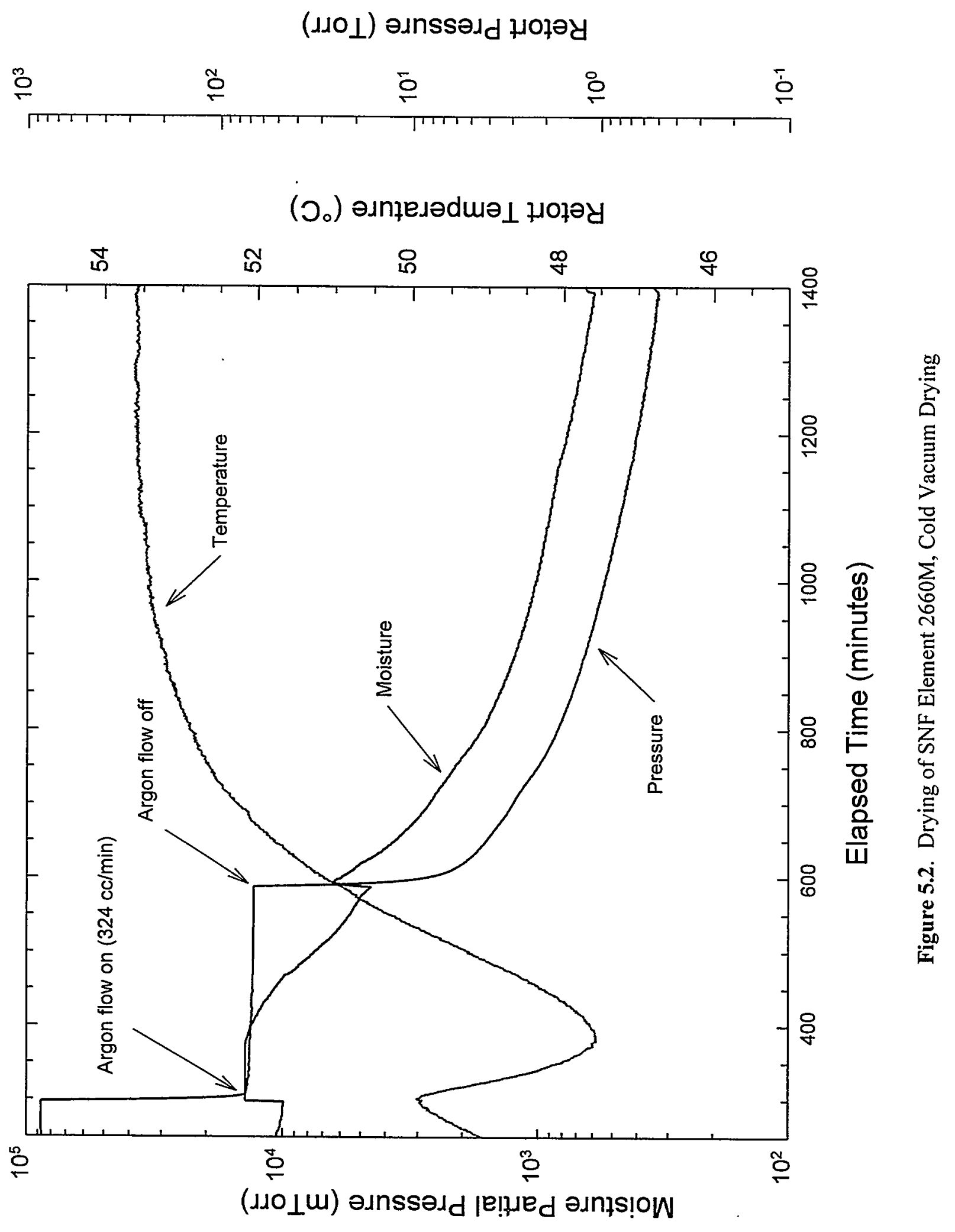


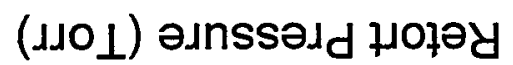

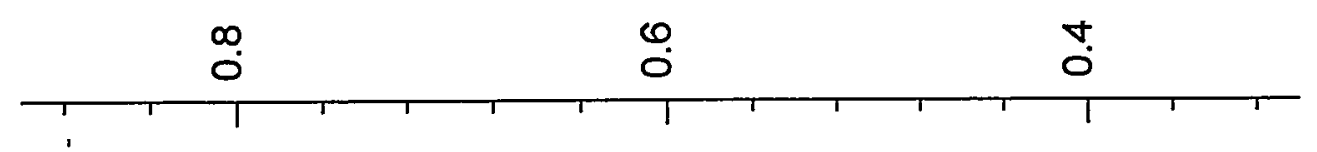

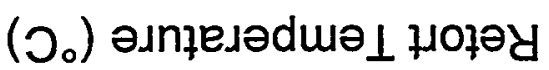

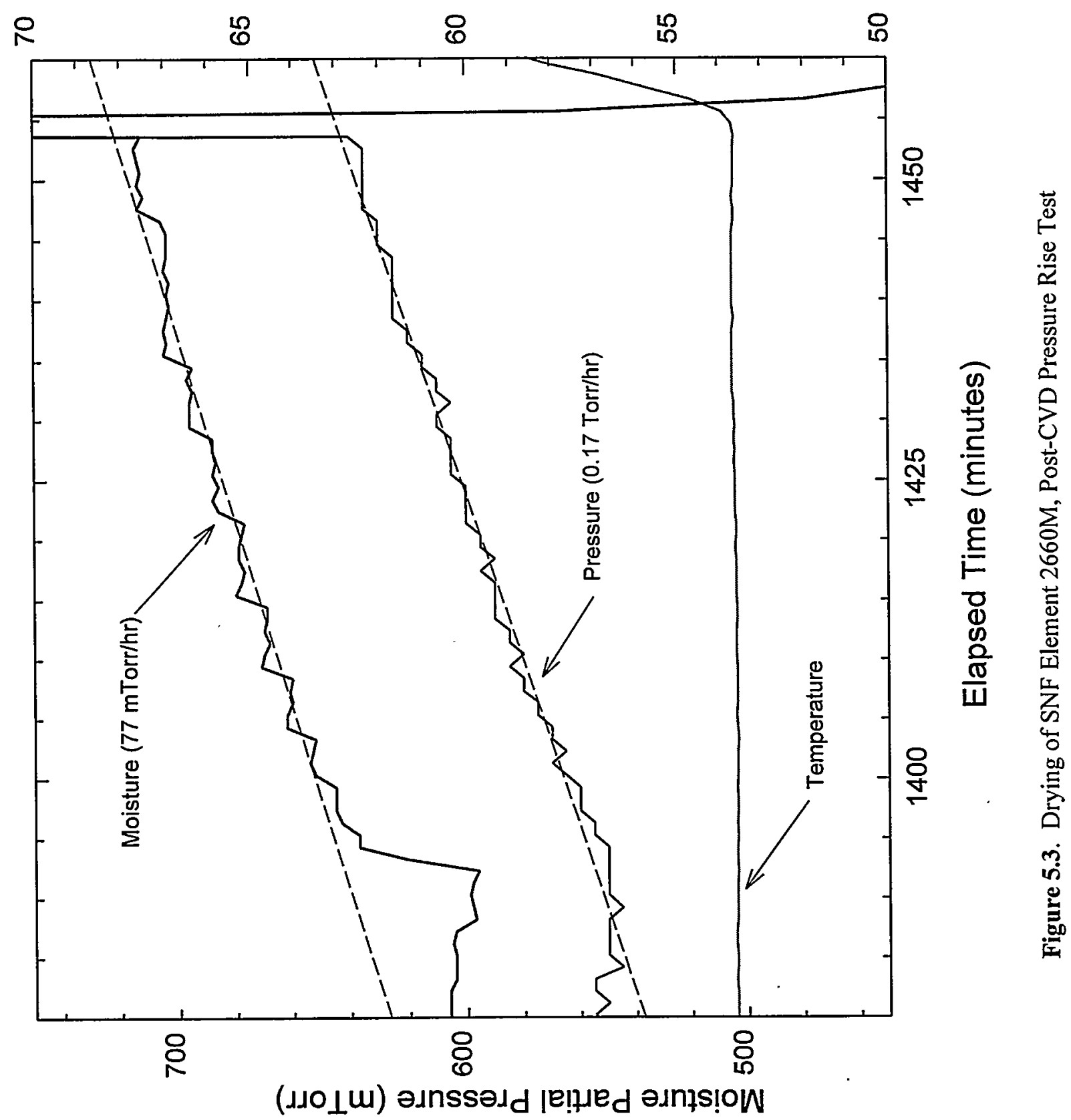




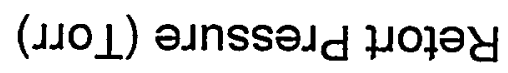
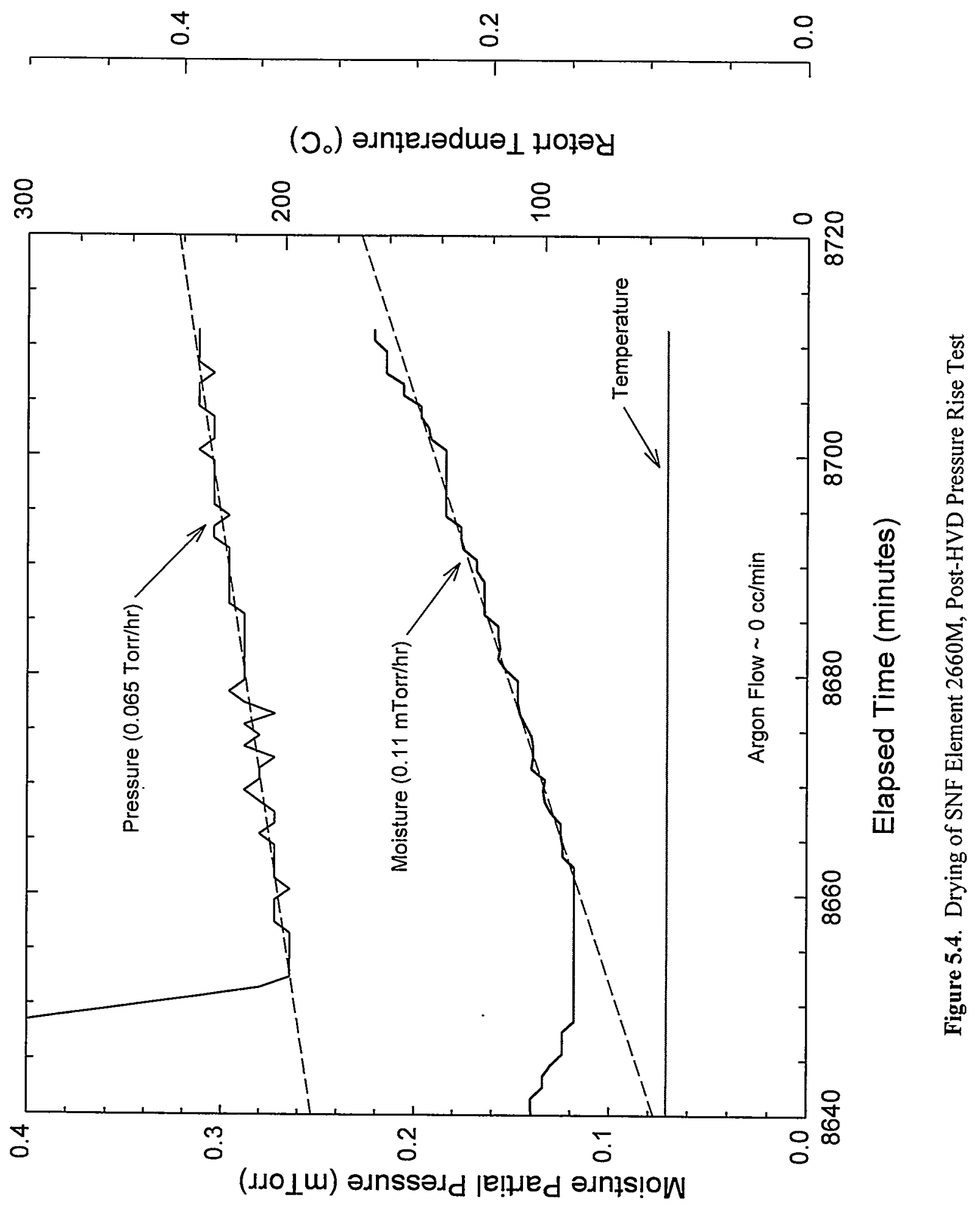
Regression fits (dotted lines in the figure) yielded a total pressure rise rate of $\sim 0.17 \mathrm{Torr} / \mathrm{hr}$ (well below the $0.5 \mathrm{Torr} / \mathrm{hr}$ criterion for the test), and a moisture pressure rise rate of $\sim 0.077 \mathrm{Torr} / \mathrm{hr}$.

Assuming that the water vapor pressure increase is from water sources within the test system, and assuming ideal gas behavior of the water vapor, the rate of desorption of the water $(d \mathrm{n} / d t)$ will be given by:

$$
\frac{d \mathrm{n}}{d \mathrm{t}}=\frac{\mathrm{V}}{\mathrm{RT}} \cdot \frac{d \mathrm{P}}{d \mathrm{t}}
$$

where $\mathrm{n}$ is the number of moles of gas, $\mathrm{V}$ is the volume of the system $\left(-10,000 \mathrm{~cm}^{3}\right), \mathrm{R}$ is the gas constant $\left(82.06 \mathrm{~cm}^{3} \cdot \mathrm{atm} / \mathrm{g}-\mathrm{mol} \cdot \mathrm{K}\right), \mathrm{T}$ is the temperature $(-326 \mathrm{~K})$, and $d \mathrm{P} / d t$ is the rate of change in the pressure given by the slope of the regression line. The total amount of water released to the system during the Pressure Rise Test is given by the integral of the above equation. Assuming a total period of $63 \mathrm{~min}$, the total amount of water released was $\sim 0.7 \mathrm{mg}$. Assuming a total surface area of $\sim 8900 \mathrm{~cm}^{2}$ for the system (total surface area of the retort, sample boat, tubing, and an outer fuel element), and $10^{15}$ atoms per $\mathrm{cm}^{2}$ as the monolayer gas density on surfaces, approximately three monolayer equivalents of $\mathrm{H}_{2} \mathrm{O}$ were evaporated.

The results of the post-HVD pressure rise measurements are shown in Figure 5.4. Again, both the total pressure and the moisture pressure show essentially linear increases with time, however with significantly lower slopes than observed earlier for the post-CVD test. The total pressure rise has a regression slope of $\sim 0.065 \mathrm{Torr} / \mathrm{hr}$, and the moisture pressure rise has a slope of $\sim 0.00011 \mathrm{Torr} / \mathrm{hr}$. The rate of increase in the total pressure is similar to that observed in the previous run (Run 6), suggesting similar system sealing conditions.

As has been observed previously, the ratio of the water pressure rise to the total pressure $(\sim 0.002)$ is somewhat lower than would be expected just from humidity alone in air in-leakage from the cell environment (air at $20^{\circ} \mathrm{C}$ and $25 \%$ relative humidity would yield a water pressure-to-total pressure ratio of 0.007 ). A likely explanation for the low moisture pressure rise in the post-HVD test is that the previous vacuum drying of the fuel element at temperature (during CVD and HVD) resulted in the formation of hygroscopic species that "gettered" most of the moisture from either air in-leakage or moisture remaining on the element that otherwise would have been released.

Comparing the pressure data from the two Pressure Rise Tests indicates that the total pressure rise observed in the initial post-CVD test is only partially caused by residual moisture and/or air in-leakage. The difference between the total pressure rise and the moisture pressure rise for the post-CVD test $(\sim 0.093 \mathrm{Torr} / \mathrm{hr})$ is significantly higher than can be explained by air in-leakage into the retort alone as measured in the post-HVD test ( $\sim 0.065 \mathrm{Torr} / \mathrm{hr})$. This suggests that other sources of gas, such as hydrogen, are responsible for some of the observed total pressure rise in the post-CVD test. 


\subsection{Hot Vacuum Drying}

The first segment of HVD, shown in Figure 5.5, includes the ramp and hold from $\sim 50^{\circ} \mathrm{C}$ to $\sim 80^{\circ} \mathrm{C}$ in flowing argon gas $(-324 \mathrm{cc} / \mathrm{min})$ under partial vacuum. HVD-1 occurred over an ET of $1456 \mathrm{~min}$ to $2926 \mathrm{~min}$. The moisture pressure decreased steadily from $\sim 570 \mathrm{mTorr}$ to $\sim 23 \mathrm{mTorr}$ during the $\sim 80^{\circ} \mathrm{C}$ phase. Total system pressure was essentially constant over this first HVD phase at $\sim 19$ Torr. Total water removed was $\sim 2.4 \mathrm{~g}$.

The second HVD phase involved maintaining the same system conditions as in HVD-1, but raising the temperature slowly from $\sim 80^{\circ} \mathrm{C}$ to $\sim 400^{\circ} \mathrm{C}$ at a rate of $10^{\circ} \mathrm{C} / \mathrm{hr}$. HVD-2 occurred over an ET of $2926 \mathrm{~min}$ to $5014 \mathrm{~min}$ and is shown in Figure 5.6. During the temperature rise, the moisture pressure increased, showing a distinct peak at $\sim 137^{\circ} \mathrm{C}(\sim 80 \mathrm{mTorr})$, with perhaps a smaller peak at $\sim 200^{\circ} \mathrm{C}$ ( $40 \mathrm{mTorr})$. As has been observed in previous tests, these peaks are an indication of water release from chemisorbed sites (i.e., hydrated species). Total water removed during the second phase of HVD was $\sim 0.9 \mathrm{~g}$, about one third of that removed during the first phase. Total system pressure was essentially constant at $\sim 19$ Torr.

The third phase of HVD is shown in the left-hand side of Figure 5.7 (ET of $5014 \mathrm{~min}$ to $5471 \mathrm{~min}$ ) and covered the temperature hold period at $\sim 400^{\circ} \mathrm{C}$. This period is characterized by a steady decrease in the moisture pressure from $\sim 3 \mathrm{~m}$ Torr to $\sim 1.5 \mathrm{mTorr}$. Total water removed was $\sim 17 \mathrm{mg}$.

Following the final HVD phase, the system was allowed to cool to $\sim 50^{\circ} \mathrm{C}$ in preparation for the posttest Pressure Rise Test discussed above. Water removed during the system cooldown was $\sim 23 \mathrm{mg}$. Total system pressure remained constant at $\sim 19$ Torr during HVD-3 and cooldown.

\subsection{Gas Chromatograph Measurements}

The GC was used to measure hydrogen in the sample gas during a portion of the CVD step and during the HVD portion, when argon was flowing through the system. As discussed earlier, the hydrogen concentration data have been converted from ppmv to Torr-l so that the absolute quantity of hydrogen gas released can be determined independent of argon flow rate. To determine the location of the hydrogen peaks during HVD and the integrated amounts of hydrogen involved with each peak, the HVD hydrogen data were deconvoluted using a commercial peak fitting computer program, PeakFit. A five-parameter asymmetrical fitting function (Pearson IV) was used to fit each of the separate deconvoluted peaks.

Hydrogen data collected during approximately the last half of the condenser pumpdown phase of CVD are shown in Figure 5.8. Hydrogen values during this phase ranged from $\sim 0.36 \mathrm{Torr} \cdot \mathrm{l} / \mathrm{min}$ to $\sim 0.22$ Torr $1 / \mathrm{min}$. Over the same period, the moisture pressure ranged from $\sim 12$ Torr to $\sim 5$ Torr. Total hydrogen release during this period was $\sim 47$ Torr $\cdot 1(\sim 5 \mathrm{mg})$. In terms of moles, the relative water-tohydrogen amounts ranged from $\sim 160$ to $\sim 90$, indicating that about $1 \%$ or less of the available water released during CVD is reacting with the fuel to produce hydrogen. 


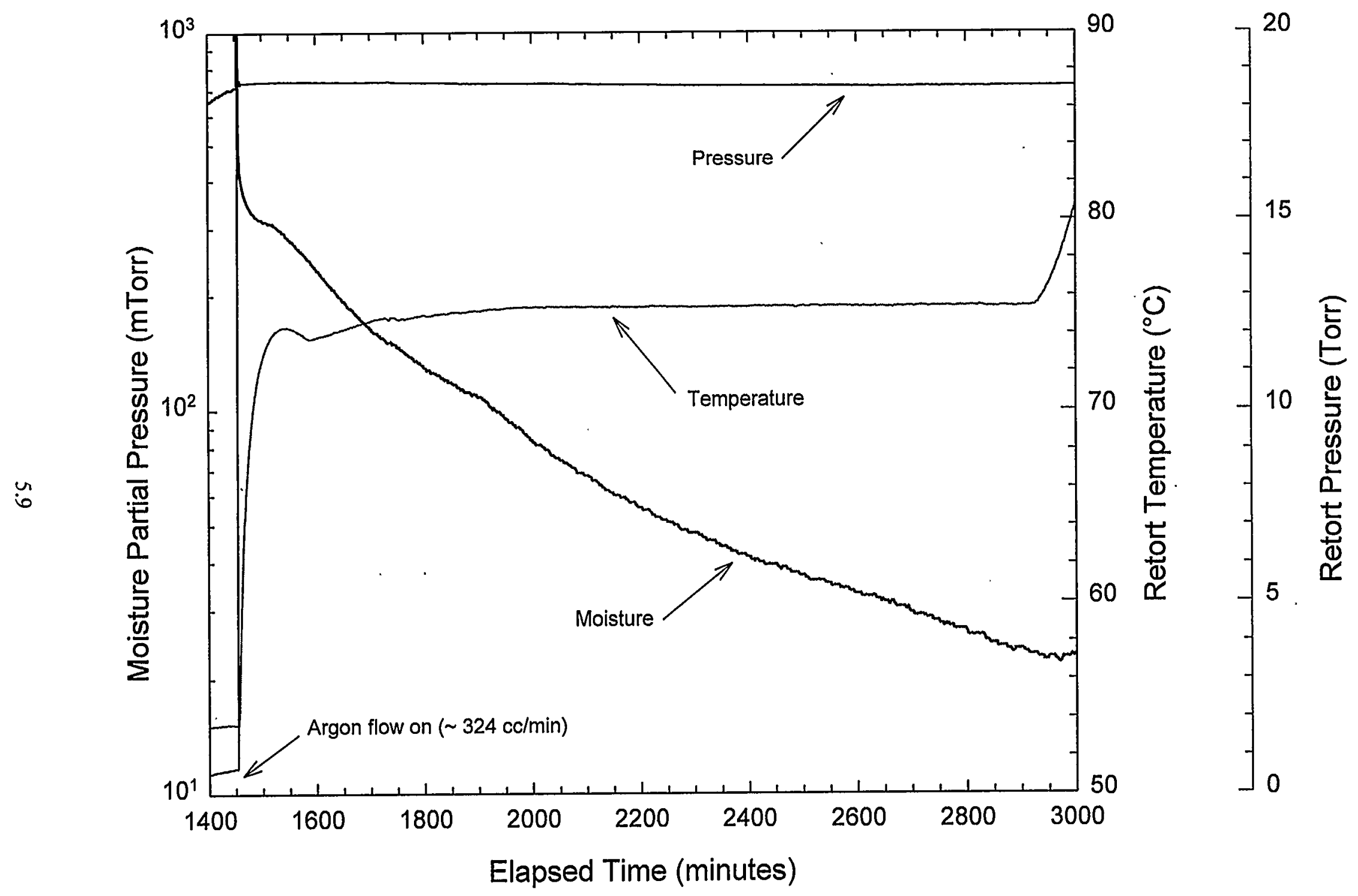

Figure 5.5. Drying of SNF Element 2660M, Hot Vacuum Drying - Step 1 

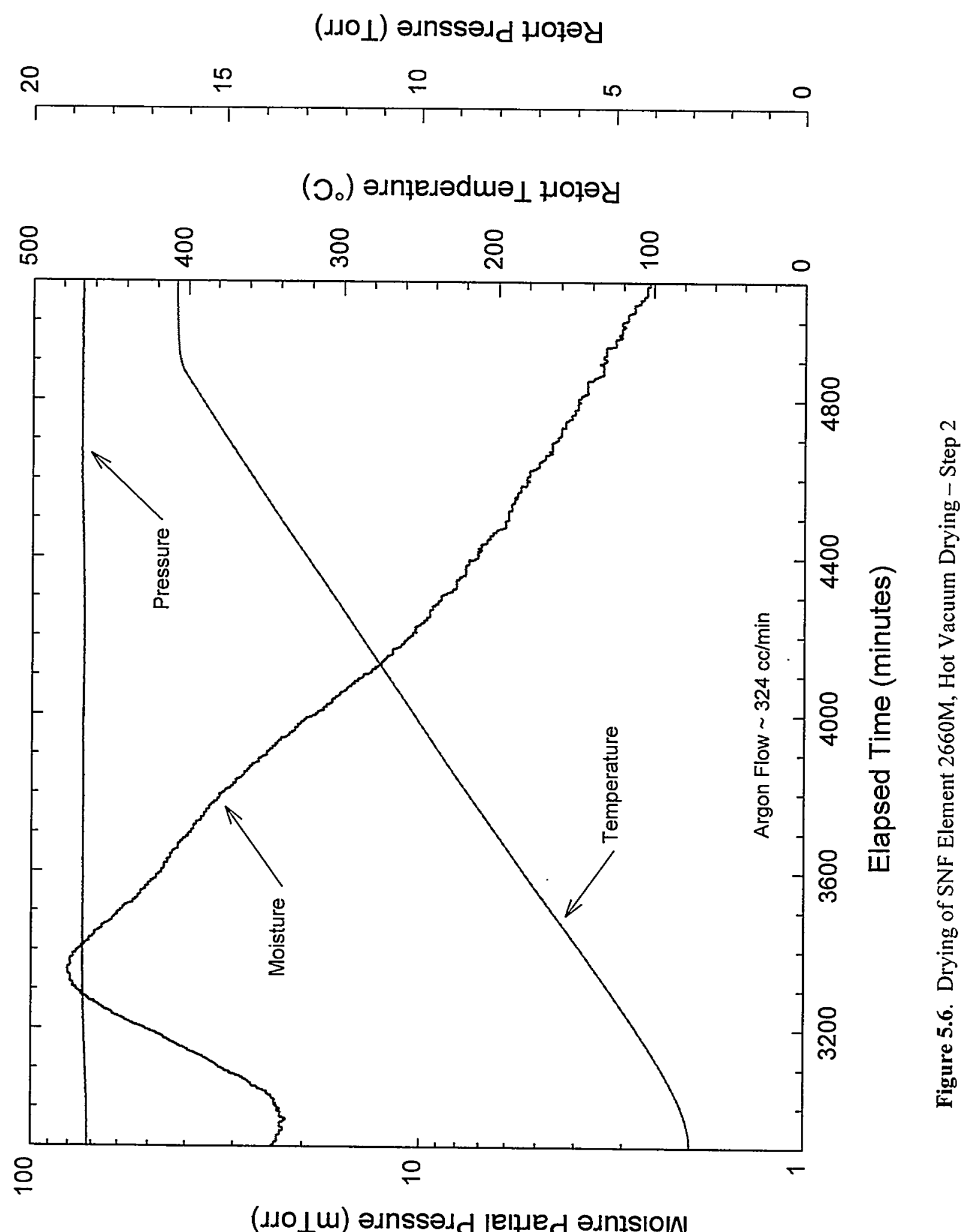


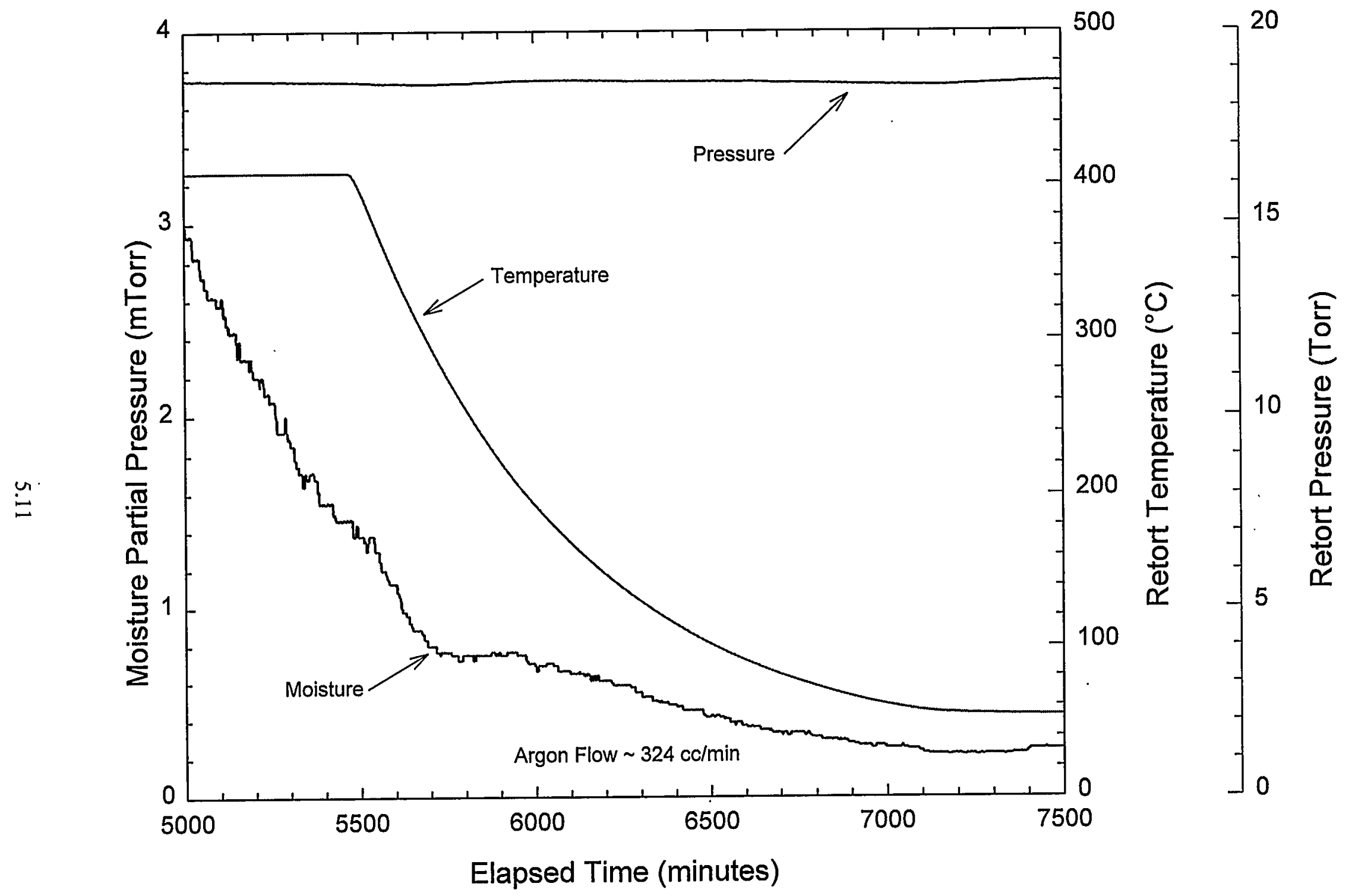

Figure 5.7. Drying of SNF Element 2660M, Hot Vacuum Drying - Step 3 

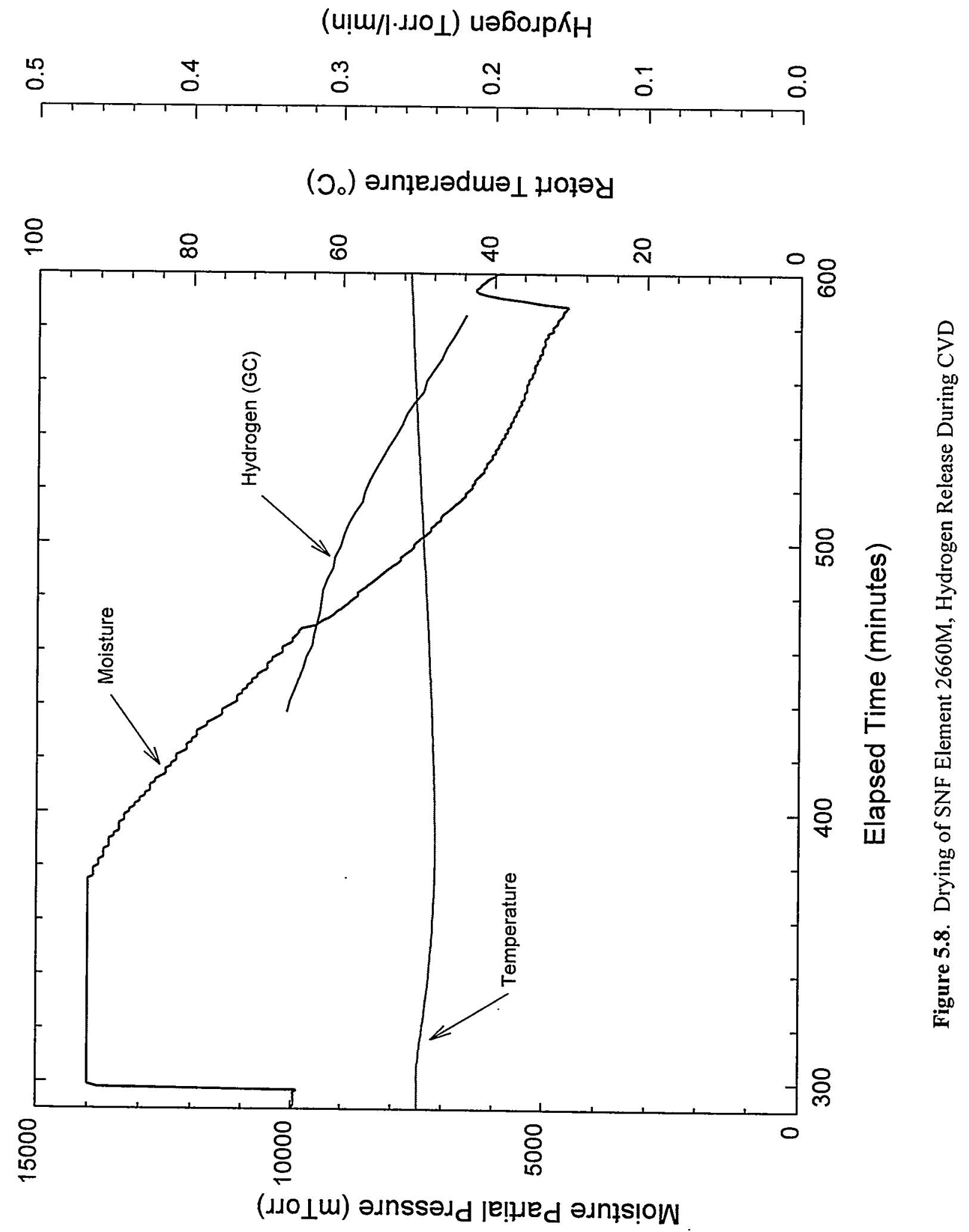
Measured hydrogen release during the HVD segments of the drying test are shown in Figure 5.9. Four peaks are associated with the hydrogen release. The first occurred during the initial phase of HVD at $\sim 75^{\circ} \mathrm{C}$ at an ET of $\sim 1600 \mathrm{~min}$. This peak was characterized by a fairly rapid rise in the hydrogen signal, followed by a slow approximately exponential decay. From deconvolution of the hydrogen data, $\sim 180$ Torr $\cdot 1(\sim 19 \mathrm{mg})$ of hydrogen were released during HVD-1. The three remaining peaks occurred during HVD-2 at temperatures of $\sim 152^{\circ} \mathrm{C}, \sim 194^{\circ} \mathrm{C}$, and $\sim 245^{\circ} \mathrm{C}$. Approximately 1900 Torr $\cdot 1$ ( $\sim 200 \mathrm{mg}$ ) of hydrogen were released during the entire HVD process, over a time period of $\sim 67$ hours, with the majority being released during HVD-2.

As noted in Section 3.2.3, HVD-1 is isothermal except for the initial temperature ramp from $\sim 50^{\circ} \mathrm{C}$ to $\sim 75^{\circ} \mathrm{C}$, and can therefore be used to provide information on reaction kinetics. During HVD-1, the hydrogen signal first increases and then later decreases steadily with time. By contrast, the water signal decreases steadily with time during HVD-1. This behavior has been observed in earlier runs and suggests that oxidation is occurring during the initial part of HVD-1 as the bulk of the fuel element reaches $75^{\circ} \mathrm{C}$, with the oxidation slowing in the latter phases of HVD-1 in concert with the drop in available moisture.

The hydrogen peaks at $152^{\circ} \mathrm{C}$ and $194^{\circ} \mathrm{C}$ during the early part of HVD-2 roughly correlate with the large water release peak occurring slightly earlier. Approximately $820 \mathrm{Torr} \cdot \mathrm{l}(\sim 89 \mathrm{mg})$ of hydrogen and $\sim 720 \mathrm{mg}$ of water were released during this time period. It is likely that the hydrogen released during this period is from oxidation of fuel by water released through oxy-hydrate decomposition in the corrosion regions or in isolated regions under the cladding. The molar ratio of water to hydrogen released was $\sim 0.9$, indicating that about $53 \%$ of the water released from the fuel by decomposition over this time period reacted with the fuel. In previous drying tests, this fraction was as large as $\sim 80 \%$.

The hydrogen peaks at $245^{\circ} \mathrm{C}$ accounted for the majority of the hydrogen release, amounting to $\sim 930$ Torr $\cdot 1(\sim 100 \mathrm{mg})$. This peak is most likely due to the decomposition of uranium hydride since there is little correlation with the water signal during this period. Also, this temperature is close to the expected temperature for $\mathrm{UH}_{3}$ decomposition (Cotton 1988). This quantity of hydrogen would represent $\sim 8 \mathrm{~g}$ of $\mathrm{UH}_{3}$ decomposition. The total quantity of hydrogen released during the HVD-2 phase was $\sim 1750$ Torr $\cdot 1$ $(\sim 190 \mathrm{mg})$.

\subsection{Mass Spectrometer Measurements}

The drying system was designed so that the Balzers Omnistar MS could be used in conjunction with the GC to collect hydrogen and other gas release data over the test run. Because of technical problems that occurred with the MS, only short sections of MS data were collected; thus no MS data are presented for this test. Earlier tests, however, have shown good correlation between the GC and MS hydrogen data. 


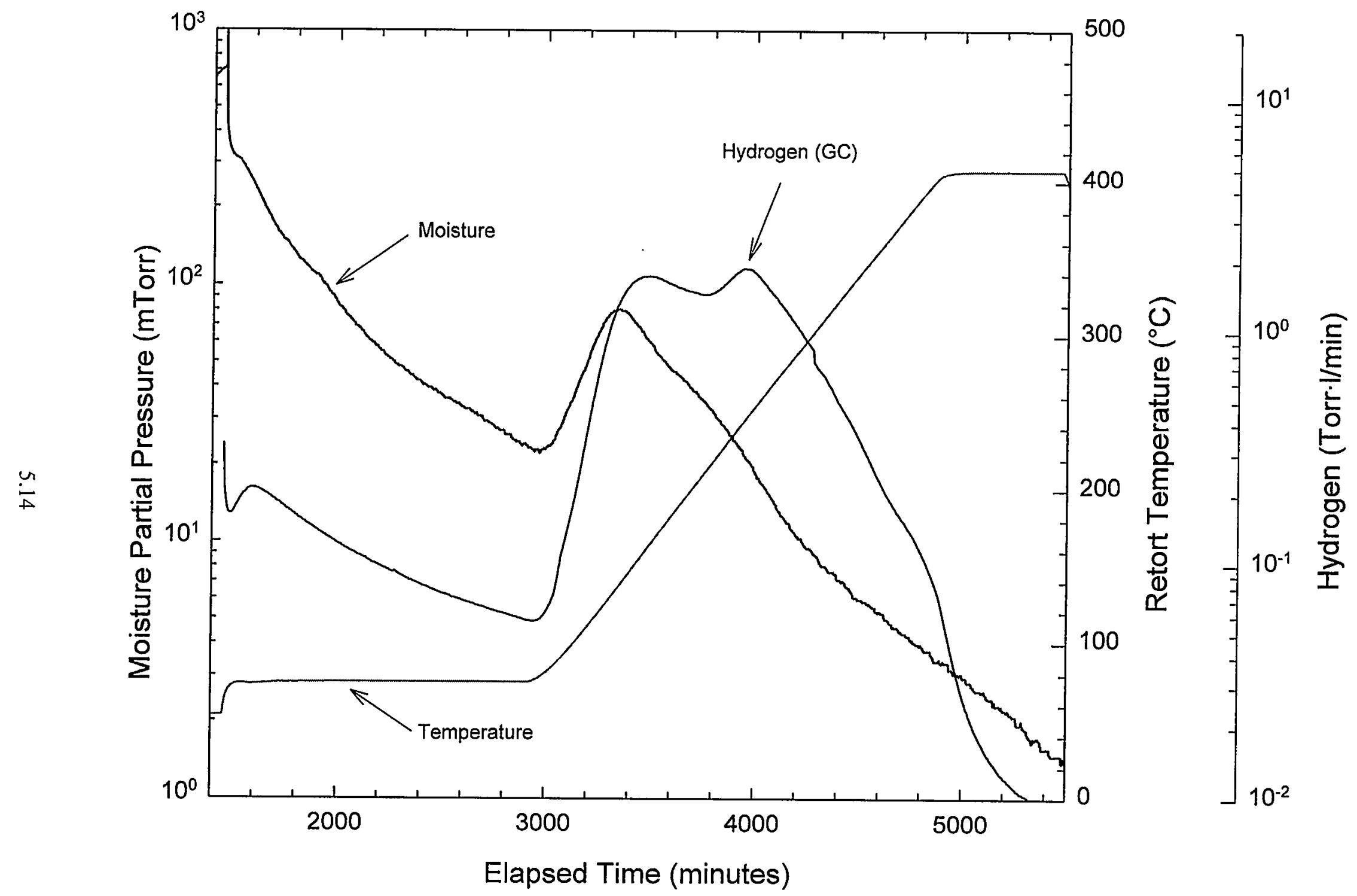

Figure 5.9. Drying of SNF Element 2660M, Hydrogen Release During HVD and Cooldown 


\subsection{Discussion}

Approximately $15 \mathrm{ml}$ of water were observed in the condenser during the condenser pumpdown phase of CVD, in reasonable agreement with that calculated from Equation 3.4 over the same time period. The extra $5 \mathrm{ml}$ of water observed over that added at the start of the test $(10 \mathrm{ml})$ may be from water . retained in the fuel element during storage. A similar excess of water was observed in Element $5744 \mathrm{U}$ (Run 4), which had similar levels of damage to the cladding.

An additional $\sim 0.7 \mathrm{mg}$ of water was removed during the post-CVD Pressure Rise Test. Therefore, this release can likely be interpreted as coming from free water that was trapped and not completely released during CVD. Similar to earlier tests, the total pressure rise observed in the post-CVD test was only partially a result of residual moisture, suggesting that other sources of gas are responsible for some of the total pressure rise observed in the post-CVD test.

During the first segment of HVD, approximately $2.4 \mathrm{~g}$ of water were removed at temperatures between $\sim 50^{\circ} \mathrm{C}$ and $\sim 80^{\circ} \mathrm{C}$. The second phase of HVD released approximately $0.9 \mathrm{~g}$ of water with a main peak at $\sim 137^{\circ} \mathrm{C}$. The final phase of HVD at $400^{\circ} \mathrm{C}$ released only about $17 \mathrm{mg}$ of water, with an additional $\sim 23 \mathrm{mg}$ of water released during post-HVD cooldown. This indicates that small residual quantities of water remained even after the drying test was completed.

Most of the water removal after the post-CVD Pressure Rise Test occurred during the first phase of $\mathrm{HVD}$, which entailed the temperature ramp from $\sim 50^{\circ} \mathrm{C}$ to $\sim 80^{\circ} \mathrm{C}$. This water release is attributed largely to the release of water from regions beneath the cladding and from under the corroded regions, although decomposition of metal oxy-hydrates may also account for some of this water. Therefore, water released from the element from isolated regions along a "tortuous path" may be the controlling factor in post-CVD water removal. The peaks in the moisture release during HVD-2 indicate water release from chemisorbed sites (i.e., hydrated species) at higher temperatures. As observed in previous drying tests, a temperature above $400^{\circ} \mathrm{C}$ may be required for complete drying of the fuel element within a reasonable period of time.

Hydrogen data were obtained from the GC during a portion of the condenser pumpdown phase of CVD and during HVD. During the CVD period, approximately $5 \mathrm{mg}$ of hydrogen were released, indicating that about $1 \%$ or less of the available water released during CVD reacted with the fuel to produce hydrogen. During HVD, hydrogen was first observed starting at the ramp-up to $\sim 75^{\circ} \mathrm{C}$, reaching a peak at $\sim 0.2$ Torr $\cdot 1 / \mathrm{min}$ before slowly decreasing. From deconvolution of the hydrogen data, $\sim 180$ Torr $\cdot$ ( $\sim 19 \mathrm{mg})$ of hydrogen were released during HVD-1, attributed to oxidation of the fuel by remaining free water. Hydrogen release increased again during the ramp from $\sim 75^{\circ} \mathrm{C}$ to $\sim 400^{\circ} \mathrm{C}$, with three noticeable peaks at $\sim 152^{\circ} \mathrm{C}, \sim 194^{\circ} \mathrm{C}$, and $\sim 245^{\circ} \mathrm{C}$. The first two peaks roughly correlated with a similar water release and amount to $\sim 820$ Torr $1(\sim 89 \mathrm{mg})$. It is likely that this hydrogen release is due to oxidation of fuel by water released through oxy-hydrate decomposition. The latter hydrogen release peak 
( $\sim 930$ Torr $\cdot 1$, or $\sim 100 \mathrm{mg}$ ) at $\sim 245^{\circ} \mathrm{C}$ is likely due to uranium hydride decomposition and is equivalent to $\sim 8 \mathrm{~g}$ of $\mathrm{UH}_{3}$ decomposed. Above $\sim 245^{\circ} \mathrm{C}$, the level of hydrogen decreased rapidly with time, with $\sim 6$ Torr $-1(\sim 0.6 \mathrm{mg})$ of hydrogen released during HVD-3. Total hydrogen release during HVD was $\sim 1900$ Torrl $(\sim 200 \mathrm{mg}$ ), roughly comparable to that observed for Element 5744U (Run 4).

Because of technical problems, no useful MS data were collected during the run. Earlier tests, however, have shown good correlation between the GC and MS hydrogen data. 


\subsection{References}

Cotton, F. A. 1988. Advanced Inorganic Chemistry, $5^{\text {th }}$ Edition. John Wiley \& Sons, New York.

CRC Press. 1997. Handbook of Chemistry and Physics, $78^{\text {th }}$ Edition. New York.

Lawrence, L. A. 1997. Strategy for Examination of the $15 \mathrm{~K}$-West Basin Fuel Elements.

HNF-SD-SNF-SP-018, DE\&S Hanford, Inc., Richland, Washington.

Ritter, G. A., S. C. Marschman, P. J. MacFarlan, and D. A. King. 1998. Whole Element Furnace Testing System. PNNL-1 1807, Pacific Northwest National Laboratory, Richland, Washington.

Westinghouse Hanford Company (WHC). 1995. Hanford Spent Nuclear Fuel Project Integrated Process Strategy for K Basins Spent Nuclear Fuel. WHC-SD-SNF-SP-005, Rev. 0, Richland, Washington. 


\subsection{Supporting Documents and Related Reports}

Gerry, W. M. 1997a. Calibration of Mass Flow Controllers. SNF-TP-012, Rev. 0, Pacific Northwest National Laboratory, Richland, Washington.

Gerry, W. M. 1997b. Calibration of Balzer Quadstar Mass Spectrometer. SNF-TP-014, Rev. 0, Pacific Northwest National Laboratory, Richland, Washington.

Gerry, W. M. 1997c. Calibration of MTI Gas Chromatograph Model M200. SNF-TP-013, Rev. 0, Pacific Northwest National Laboratory, Richland, Washington.

Serles, J. A. 1997. Furnace Testing of N-Reactor Fuel Element 2660M. PTL-007, Rev. 0, Pacific Northwest National Laboratory, Richland, Washington.

Reports are written separately for the whole element drying test series as follows:

System Design Description for the Whole Element Furnace Testing System

Spent Fuel Drying System Test Results (First Dry-Run)

Spent Fuel Drying System Test Results (Second Dry-Run)

Spent Fuel Drying System Test Results (Dry-Run in Preparation for Run 8 [Third Dry-Run])

Drying Results of K-Basin Fuel Element 1990 (Run 1)

Drying Results of K-Basin Fuel Element 3128W (Run 2)

Drying Results of K-Basin Fuel Element 0309M (Run 3)

Drying Results of K-Basin Fuel Element 5744U (Run 4)

Drying Results of K-Basin Fuel Element 6603M (Run 5)

Drying Results of K-Basin Fuel Element 1164M (Run 6)

Drying Results of K-Basin Fuel Element 2660M (Run-7)

Drying Results of K-Basin Fuel Element 6513U (Run 8). 


\section{Distribution}

No. of

Copies

\section{OFFSITE}

C. L. Bendixsen

Idaho National Engineering and

Environmental Laboratory

P.O. Box 1625

Mail Stop 3135

Idaho Falls, ID 83415

\section{A. W. Conklin}

Washington State Department of Health

Airdustrial Park

Building 5, Mail Stop LE-13

Olympia, WA 98504-0095

M. A. Ebner

Idaho National Engineering and

Environmental Laboratory

P.O. Box 1625

Mail Stop 3114

Idaho Falls, ID 83415

\begin{abstract}
A. R. Griffith
U.S. Department of Energy, Headquarters 19901 Germantown Rd (EM-65)

Germantown, MD 20585-1290
\end{abstract}

\section{T. J. Hull}

U.S. Department of Energy, Headquarters 19901 Germantown Road (EH-34)

Germantown, MD 20874-1290

M. R. Louthan

Savannah River Technology Center

Materials Technology Center

Aiken, SC 29808
No. of

Copies

T. E. Madey

Rutgers University

Bldg. 3865

136 Freylinghuysen $\mathrm{Rd}$

Piscataway, NJ 08854

B. K. Nelson

U.S. Department of Energy, Headquarters 19901 Germantown Road (EM-65)

Germantown, MD 20874-1290

R. G. Pahl, Jr.

Argonne National Laboratory

P. O. Box 2528

Idaho Falls, ID 83403

R. S. Rosen

Lawrence Livermore National Laboratory 20201 Century Blvd., $1^{\text {ST }}$ Floor

Germantown, MD 20874

D. Silver

Washington State Department of Ecology

P.O. Box 47600

Olympia, WA 98504-7600

T. A. Thornton

Yucca Mountain Project M\&O Contractor SUM1/423

1261 Town Center Drive

Las Vegas, NV 89134

Distr.1 
No. of

Copies

ONSITE

\section{DOE Richland Operations Office}
R. M. Hiegel
S7-41
P. G. Loscoe
S7-41
C. R. Richins
K8-50
E. D. Sellers
S7-41
J-S. Shuen
S7-41
G. D. Trenchard
S7-41

22 Duke Engineering and Services, Hanford, Inc.

C. B. Aycock

R3-11

R. B. Baker

$\mathrm{H} 0-40$

D. W. Bergmann

X3-79

S. A. Chastain

$\mathrm{H} 0-40$

D. R. Duncan

R3-86

J. R. Frederickson

R3-86

L. H. Goldmann

S. L. Hecht

B. J. Makenas

A. L. Pajunen

R. W. Rasmussen

A. M. Segrest

J. A. Swenson

C. A. Thompson

D. J. Trimble (5)

D. J. Watson

J. H. Wicks, Jr.

SNF Project Files

3 Fluor Daniel Hanford

E. W. Gerber

R3-11

D. A. Smith

T4-13

M. J. Wiemers

$\mathrm{H} 0-40$

$\mathrm{H} 0-40$

R3-86

$\mathrm{X} 3-85$

R3-11

R3-11

R3-86

$\mathrm{H} 0-40$

X3-79

$\mathrm{X} 3-74$

R3-11

R3-11
No. of

Copies

2 Fluor Daniel Northwest
L. J. Garvin
R3-26
G. A. Ritter
$\mathrm{H} 0-40$

7 Numatec Hanford Company
G. P. Chevrier
H5-25
T. Choho
R3-86
E. R. Cramer
$\mathrm{H} 0-34$
T. A. Flament
H5-25
J. J. Irwin
R3-86
C. R. Miska
R3-86
J. P. Sloughter
H5-49

2 Technical Advisory Group

J. C. Devine

R3-11

R. F. Williams

R3-11

32 Pacific Northwest National Laboratory
J. Abrefah (7) P7-27

J. P. Cowin K8-88

S. R. Gano K2-12

W. J. Gray P7-27

B. D. Hanson P7-27

G. S. Klinger P7-22

D. K. Kreid K7-80

P. J. MacFarlan P7-27

S. C. Marschman (5) P7-27

B. M. Oliver P7-22

R. P. Omberg K7-80

T. M. Orlando K8-88

L. R. Pederson K2-44

J. K. Tarantino K9-41

J. C. Wiborg K7-74

Information Release (7) 